\title{
The Role of Serology Testing in the Context of Immunization Policies for COVID-19 in Latin American Countries
}

\author{
Carlos E. dos Santos Ferreira ${ }^{1,2,3}$, Hector Gómez-Dantés ${ }^{4}$, Nancy C. Junqueira Bellei ${ }^{5}$, Eduardo López ${ }^{6,7,8}$, \\ Katya A. Nogales Crespo ${ }^{9, *}$ (D), Miguel $O^{\prime}$ Ryan ${ }^{10,11,12}$ and Julieta Villegas ${ }^{9}$
}

check for updates

Citation: dos Santos Ferreira, C.E.; Gómez-Dantés, H.; Junqueira Bellei, N.C.; López, E.; Nogales Crespo, K.A.; O'Ryan, M.; Villegas, J. The Role of Serology Testing in the Context of Immunization Policies for COVID-19 in Latin American Countries. Viruses 2021, 13, 2391. https://doi.org/ $10.3390 / \mathrm{v} 13122391$

Academic Editors: Eurico Arruda, José Luiz Proença Módena, William Marciel de Souza and Helena Lage Ferreira

Received: 30 September 2021 Accepted: 18 November 2021 Published: 29 November 2021

Publisher's Note: MDPI stays neutral with regard to jurisdictional claims in published maps and institutional affiliations.

Copyright: (c) 2021 by the authors. Licensee MDPI, Basel, Switzerland. This article is an open access article distributed under the terms and conditions of the Creative Commons Attribution (CC BY) license (https:/ / creativecommons.org/licenses/by/ $4.0 /)$.
1 Clinical Pathology, Hospital Israelita Albert Einstein, São Paulo 05652-900, Brazil; carlos.ferreira@einstein.br

2 Microbiology Sector, Federal University of São Paulo's Central Laboratory Activities, São Paulo 04088-002, Brazil

3 Brazilian Society of Clinical Pathology and Laboratory Medicine, Rio de Janeiro 22220-040, Brazil

4 National Institute of Public Health, Cuernavaca 62100, Mexico; hector.gomez@insp.mx

5 Infectious Diseases Division, Federal University of Sao Paulo, São Paulo 04039-032, Brazil; nbellei@uol.com.br

6 Department of Medicine, Hospital de Niños Gutiérrez, Buenos Aires C1425-EFD, Argentina; elopez2676@gmail.com

7 Pediatric Infectious Diseases Program, Faculty of Medicine, University of Buenos Aires, Buenos Aires C1121-ABG, Argentina

8 Pediatrics and Vaccinology, Faculty of Medicine, University of Salvador, Buenos Aires C1055-AAG, Argentina

9 Policy Wisdom LLC, Miami, FL 33173, USA; jvillegas@policywisdom.com

10 Institute of Biomedical Sciences, Faculty of Medicine, University of Chile, Santiago de Chile 8380000, Chile; moryan@med.uchile.cl

11 Millennium Institute of Immunology and Immunotherapy, University of Chile, Santiago de Chile 8331150, Chile

12 Chilean Academy of Medicine, Santiago de Chile 6500445, Chile

* Correspondence: kcrespo@policywisdom.com

\begin{abstract}
This review aims to explore the role and value of serology testing in the context of COVID-19 immunization policies in Latin American countries and the barriers and challenges to the adequate use and uptake of this tool. It builds on a review of the academic literature, evidence, and existing policies, and includes a multistage process of discussion and feedback by a group of five experts. Regional and country-level evidence and resources from five focus countries-Argentina, Brazil, Chile, Colombia, and Mexico-were collected and analyzed. This review contains an overview of (1) the impact of the SARS-CoV-2 pandemic, the variants of concern and current testing strategies, (2) the introduction of COVID-19 vaccination, (3) the potential use of serology testing to support immunization initiatives, (4) the current frameworks for the use of serology testing in the region, and (5) the barriers and challenges to implementing serology testing in the context of COVID-19 immunization policies, including a discussion on the potential actions required to address these barriers and facilitate the uptake of this strategy in the region. Stakeholders can use elements of this document to guide timely decision-making, raise awareness, and inspire further studies.
\end{abstract}

Keywords: COVID-19; SARS-CoV-2; pandemic; serology tests; antibody tests; diagnostic tests; health policy; immunization; vaccination; Latin America

\section{Methodology}

Methodologically, this paper builds on a review of literature and policies and a multistage process of discussion, validation, and feedback with a group of five experts from Latin America (LATAM). These experts were selected based on academic merit in various areas of knowledge such as microbiology, epidemiology, public health, pharmacology, and infectiology. An in-depth understanding of serology testing, immunization policies, and the current COVID-19 pandemic was deemed essential. Experience in seroprevalence, seroepidemiology, and post-marketing vaccine effectiveness studies was considered an asset. 
This review was inspired by a similar project conducted in Europe [1], adopting a similar framework for the collection of data. As the first step, six primary topics were identified: (1) the impact of the pandemic in the LATAM region and focus countries, (2) current testing strategies, (3) national COVID-19 vaccination policies of focus countries, (4) current policies on the use of serology testing, (5) literature on the use of serology testing in immunization programs, and (6) barriers and challenges limiting implementation.

Evidence on the epidemiological impact was retrieved from well-known monitoring databases, paying particular attention to the countries of interest. Evidence on the socioeconomic impact of the pandemic and the policy frameworks and recommendations for the use of serology testing were extracted from reports of leading international organizations, such as the Organization for Economic Co-Operation and Development, Inter-American Development Bank, International Monetary Fund, Americas Society, Economic Commission for Latin America and the Caribbean, World Health Organization (WHO), PanAmerican Health Organization (PAHO), United States Food and Drug Administration (FDA), and Centers for Disease Control and Prevention (CDC). Evidence on the characteristics of serology tests and the use of serology testing in various immunization programs were retrieved from academic publications in peer-reviewed journals (where possible). The national COVID-19 vaccination policies and policies for the use of serology testing of focus countries were retrieved from the official government portals. Finally, the barriers and challenges were identified using all the reviewed sources.

Regional and country-level evidence, policies, and guidelines from five focus countriesArgentina, Brazil, Chile, Colombia, and Mexico-were collected and analyzed. Resources were prioritized using the following inclusion criteria:

- Scientific perspectives on SARS-CoV-2 testing strategies, including challenges and opportunities;

- The health and socioeconomic impact of the pandemic in the region;

- The current position, guidelines, and recommendations on the use of serology testing from key international organizations and focus countries;

- Progress on COVID-19 immunization roll-out and coverage in countries of focus; and

- The national COVID-19 immunization plans and/or strategies of the focus countries.

The information gathered was synthetized and organized, creating a working document. This document served as the basis for the discussion, validation, and feedback provided by all experts during three online panel sessions and rounds of offline review. The working document was edited until the experts reached a consensus.

\section{Introduction: The Impact of the Pandemic in the Region}

On 31 December 2019, the Chinese authorities reported a novel coronavirus causing a cluster of pneumonia-like cases in Wuhan in Hubei Province of China. The virus was later named SARS-CoV-2, and the disease caused by this new virus was named COVID-19 [2]. Between 26 February and 6 March 2020, health officials confirmed cases of COVID-19 in LATAM countries, including Argentina, Brazil, Chile, Colombia, and Mexico [3]. As the new infection spread rapidly across the globe, WHO characterized the COVID-19 outbreak as a pandemic of global proportions on 11 March 2020 [2].

As of 28 October 2021, WHO has reported 244,897,177 confirmed cases of COVID-19, leading to 4,970,429 deaths worldwide [4]. While Europe was profiled as the worst-hit region during the first months of the pandemic, this spot was rapidly overtaken by the Americas. With 93,244,907 confirmed cases and 2,285,843 deaths [4], the Americas is currently profiled as the region with the highest cumulative mortality from COVID-19, accounting for $46 \%$ of the total number of deaths worldwide [5]. Within the Americas, LATAM countries have been the worst hit by the pandemic. Whereas reported deaths number about 65 per 100,000 people globally, this increases to 239 deaths per 100,000 people in LATAM [6].

Based on cumulative deaths as of 28 October 2021, the worst affected countries in the region are Brazil $(606,679)$, Mexico $(286,888)$, Peru $(200,149)$, and Colombia $(127,159)[6]$. 
Examining the focus countries, Brazil, Colombia, and Argentina have recorded a considerable higher mortality rate compared to Chile and Mexico (see column two Table 1) [6]. However, according to the case fatality ratio, Mexico performs substantially poorer than other countries in the region, recording a 7.6\% death ratio for every 100 confirmed COVID-19 cases (which positions the country among the first three globally) [7]. Furthermore, a study in Mexico revealed an excess mortality of 43.1\% in 2020 (493,503 deaths attributed to all causes), of which $71.2 \%$ are attributed to COVID-19 [8,9].

Table 1. Impact of the pandemic in focus countries: Argentina, Brazil, Chile, Colombia, and Mexico.

\begin{tabular}{lccc}
\hline \multicolumn{1}{c}{ Country } & $\begin{array}{c}\text { Death Reported by 100 K } \\
\text { Habitants [6] } \\
\text { (as of 27 October 2021) }\end{array}$ & $\begin{array}{c}\text { 14-Day Notification Death Rate } \\
\text { per 1 M Inhabitants [10] } \\
\text { (as of 28 October 2021) }\end{array}$ & $\begin{array}{c}\text { Case Fatality Ratio * [7] } \\
\text { (as of 28 October 2021) }\end{array}$ \\
\hline Argentina & 258 & 7.96 & $2.2 \%$ \\
Brazil & 287 & 21.79 & $2.8 \%$ \\
Chile & 199 & 5.96 & $2.2 \%$ \\
Colombia & 253 & 8.72 & $2.5 \%$ \\
Mexico & 225 & 24.19 & $7.6 \%$ \\
\hline
\end{tabular}

${ }^{*}$ Case-fatality ratio: number of deaths per 100 confirmed cases. Source: based on available data from the Inter-American Development Bank, the European Center of Disease Prevention and Control, the World Health Organization, and the Johns Hopkins University and Medicine Coronavirus Resource Center.

Nevertheless, it is important to emphasize that as challenges related to the detection and reporting of cases and deaths across the region arise, many have expressed concerns regarding the accuracy of these numbers to reflect the real impact of the pandemic, which considerably limits efforts to compare impact across countries. These challenges include differences in how cases are defined and considerable delays in reporting cases and deaths.

Besides the direct human impact of COVID-19, the pandemic has also severely affected health systems and population health. LATAM countries have experienced severe shortages of essential medicines and equipment to treat COVID-19, personal protective equipment, and health care personnel throughout the pandemic [11,12]. Moreover, due to reduced access to health care, the pandemic has also worsened conditions for those living with chronic illnesses, especially non-communicable diseases [13,14]. Reports have also identified an increase in mental health disorders, particularly anxiety, depression, and suicide $[15,16]$. In LATAM, these conditions have been found to most commonly affect health care workers and young people $[17,18]$. The dramatic shift in health priorities has also led to a relocation of health budgets and priorities and a lag in vaccination schedules that target other vaccine-preventable diseases $[19,20]$.

The pandemic has also created socio-political externalities. In many cases, pre-existing social unrest has challenged governments' capacity to respond to the pandemic comprehensively [21,22]. Concerns about leaders taking advantage to advance their agendas and restrict freedom of expression have also been heard across the region [23].

Measures to combat the pandemic have affected the most vulnerable sectors of society to a larger extent. Reports estimate that approximately $40 \%$ of formal workers and $65 \%$ of informal workers have no social safety net, including health care coverage [11,24]. In many countries, informal workers, representing up to $60 \%$ of the labor market, have struggled to comply with public health measures such as social distancing, quarantines, and mandatory stay-at-home orders [11,24]. Likewise, following hygiene and social distancing measures has proven very difficult for the $21 \%$ of Latin America's urban population that resides in slums, informal settlements, or substandard housing [25,26].

Gender inequalities have also soared during the pandemic. Women, representing 70\% of health workers in the region, have been disproportionally exposed to the virus [27]. This has been accompanied by an increased care-related pressure at home [11], deterioration of work-life balance [28], and increased gender-based and domestic violence [28,29]. Finally, school closures have impacted the quality of education and raised concerns with regard 
to subsequent inequalities on food security, school dropout, and access to the necessary equipment to continue with distance learning in the most vulnerable households [30-32].

\section{Measures to Respond to the SARS-CoV-2 Pandemic in the Region}

During the first year of the pandemic, most countries in the region responded with severe containment measures, such as declaring states of emergency and instituting national quarantines between March and October 2020. Evidence suggests that federal states, such as Mexico and Brazil, experienced a delay in implementing such restrictions due in part to the decentralized nature of their governments. Similarly, a closer look at non-pharmaceutical interventions enforced in the countries of focus reveals that, compared to centralized states, federal states enforced fewer restrictions through the central government. In these scenarios, most policies were eventually adopted and adapted by subnational governments [11].

Nevertheless, various non-pharmaceutical interventions, varying substantially in nature and stringency, have been implemented across countries. These interventions include containment and closure policies to reduce the spread of the virus, health system policies to reinforce capacity to manage the pandemic, immunization policies, and economic policies to support vulnerable households and affected sectors of the economy [33].

While all LATAM countries applied containment and closure measures to reduce the spread of the virus, few governments implemented economic policies to protect individuals and businesses and furthermore support adherence to these restrictions. Countries such as Mexico and Paraguay are currently enforcing looser restrictions than Argentina, Chile, Colombia, and Peru [34]. However, health officials recorded a resurgence of COVID-19 cases between April and May 2021, primarily affecting younger population segments. As younger patients are more likely to survive and remain hospitalized for extended periods, there is concern regarding the capacity of health systems to cope with an increase in hospitalizations. Following this trend, PAHO has urged countries in the region to increase the capacity of intensive care units [5].

Implementing non-pharmaceutical interventions that limit mobility and the regular functioning of businesses has sparked fear of an economic crisis. Decisions regarding how to reduce the effects of the pandemic on mortality without compromising the economy any further will continue to be challenging. To date, evidence has shown that measures have negatively affected the supply and demand chain of products and services across economic sectors $[32,35,36]$, particularly affecting the food industry, hospitality, tourism, and aviation [32,36,37]. The fall in commodity prices has also caused a sharp drop in LATAM markets and currencies [38]. The International Monetary Fund estimated a 7\% economic contraction in the region [23], expected to cause the worst recession in history [11]. In 2020 alone, $13.5 \%$ of people in LATAM became unemployed [39], and 22 million fell into poverty (an increase of $33.7 \%$ overall) [23], mainly affecting Argentina, Brazil, Mexico, and Peru [39].

Reducing the impact of the pandemic on the economy and people's health and wellbeing requires effective policies that can help accelerate the return to normalcy. Vaccination has long been perceived as one of the main strategies to respond to the pandemic, triggering a massive effort to develop COVID-19 vaccines in record time. Governments of LATAM introduced COVID-19 vaccines in December 2020. With limited availability of resources and vaccine doses in many LATAM countries, tools that can help vaccination campaigns be carried out in the most effective and efficient way possible are extremely valuable. SARS-CoV-2 serology testing can provide important information to support decision-making regarding the containment and mitigation of COVID-19. According to information from other vaccine preventable diseases, within COVID-19 immunization policies, serology testing might play an important role in ensuring the effective planning, implementation and monitoring of immunization programs, as well as support endeavors to monitor and study the effectiveness of vaccines during immunization roll-out. This review will introduce the key aspects that shape the current pandemic scenario (the impact 
of virus mutations and the introduction of vaccination) while exploring potential avenues for the use of serology testing, based on current policy frameworks and available evidence.

This review has three goals: (1) to provide an overview of the role and value of serology testing as a tool to support COVID-19 immunization policies in LATAM, (2) to identify the barriers and challenges to the use and uptake of this tool in the current pandemic scenario, and (3) to provide an overview of the potential actions required to address these barriers and facilitate the uptake of this strategy in the region. International, national, and local health policy decision-makers involved in planning COVID-19 vaccination programs and strategies, the academic community, medical societies, as well as other stakeholders can use elements of this document to inspire further studies and build the necessary partnerships and alliances for collaborative actions.

\section{Variants of Concern in Latin America}

According to the WHO, as of October 2021, four variants of SARS-CoV-2 are classified as 'variants of concern' (VOC) - Alpha, Beta, Gamma, and Delta—first identified in the United Kingdom, South Africa, Brazil, and India, respectively [4]. According to current global genetic epidemiology, Delta has outcompeted other variants, including other VOCs in most counties. Nonetheless, subregional and country-level variations have been observed, particularly in LATAM, where the progression of Delta has been more gradual [4]. As of 26 October, Argentina, Brazil, Chile, and Mexico had identified cases of all four VOC; meanwhile, Colombia has only identified cases of VOC Alpha, Gamma, and Delta [4]. It is worth clarifying that this information refers to the identification of cases, but not necessarily the existence of community transmission of the VOC.

The emergence of virus mutations has been accompanied by concerns regarding their effect on transmissibility, severity of disease, immunity, and effectiveness of diagnostic methods. Evidence suggests an increased transmissibility of all VOC [40-47], and in particular a higher viral load in cases of Delta (when compared to Beta and non-VOC SARS-CoV-2 strain) $[48,49]$ and a higher risk of pre-symptomatic transmission and secondary attack [48]. Regarding the impact on the severity of disease, studies have found a potential increased risk of hospitalization associated with all VOCs [50-55]. Notably, cases of infection from Gamma, Beta, and Delta were found to be at a considerably higher risk of hospitalization compared to cases from Alpha [56] and non-VOC SARS-CoV-2 strains [53,54]. Preliminary evidence points to the possible increased risk of hospital mortality associated with VOC Beta [57,58].

Evidence on the impact that VOC may have on immunity suggests a potential increased risk of reinfection for all VOC [45,51-54,57-62]. Researchers have reported a reduced neutralizing activity in VOC Beta [63-66] and Delta [67]. In the case of Gamma, evidence indicates only a moderate reduction in neutralizing activity $[68,69]$. Contrastingly, evidence points at retained neutralizing activity [70] and a similar risk of reinfection to the original virus strain in the case of Alpha [71,72].

Regarding the impact on vaccines effectiveness, it is worth noting that the evidence varies greatly depending on the VOC and the type of vaccine being studied. Having said that, evidence from a number of retrospective studies on periods of high incidence of the VOC and studies conducted in outbreak prompt settings indicates that vaccines grant similar protection against infection from Alpha $[62,73,74]$ and Delta $[62,74,75]$ to that expected for the vaccine. More importantly, evidence suggests the retention of the effectiveness of vaccines in reducing the severity of disease for Alpha [73,74,76,77], Beta [78-81], and Delta [82]. Nonetheless, other studies indicate a potential reduction in vaccine effectiveness against symptomatic disease for Beta [78-81] and Delta [82]. The impact of Gamma on vaccines effectiveness remains unclear.

WHO, PAHO, and the FDA have expressed concern regarding the potential loss of test performance as new variants emerge [83-85]. As a result, WHO recommends a diagnostic approach using different assays in parallel or multiplex assays targeting different viral genes [84]. PAHO recommends strengthening existing disease control activities and, 
where appropriate, adjusting public health and social measures to reduce the transmission of VOC [85].

\section{Testing Strategies to Mitigate Impact: The Use of Serology Tests}

There are currently two primary types of tests for COVID-19: (1) those used to diagnose acute infection through the direct detection of genetic material of the virus or specific viral antigens (molecular tests, antigen tests) and (2) those used to evaluate the antibody response (serology tests). Serology tests can provide essential information and evidence for research and policy-making purposes. Given the scope of this document, we will introduce the main characteristics of serology tests in this section.

Serology tests are designed to detect antibodies in the serum within days to weeks following acute infection [86,87]. The presence of antibodies can indicate that a person was infected with SARS-CoV-2, irrespective of whether the individual experienced severe, mild, or no symptoms. As such, serological data have an important place in the ongoing response to the COVID-19 pandemic, assisting surveillance activities, estimating epidemiological variables, assessing the effect of non-pharmaceutical interventions at the population level [88], and helping to evaluate vaccine efficacy and the immunological response triggered by both immunization and natural infection [89].

Serology tests vary depending on the choice of antibodies. Serology tests can measure three types of antibodies: immunoglobulin M (IgM), immunoglobulin G (IgG), and immunoglobulin A (IgA). However, the most commonly used are $\operatorname{IgM}$ and $\operatorname{IgG}$, which are the two main isotypes of antibodies [13]. The specificities of tests measuring IgM/IgG and IgM are reportedly high, ranging from $96.6 \%$ to $99.7 \%$, respectively [90,91]. According to a meta-analysis, sensitivity (for IgG and IgM tests) varies according to the testing method, but can be as high as $99 \%$. Sensitivity was found to be higher (90-96\%) for enzyme-linked immunosorbent assays (ELISA) and chemiluminescence enzyme immunoassays (CLIA), than for lateral flow immunoassays (LFIA) and fluorescence immunoassays (FIA), which range between $80 \%$ and $89 \%$ [91]. Evidence suggests that SARS-CoV-2 antibody production may differ from the typical scenario, with IgM and IgG antibodies tending to rise almost simultaneously [92-94]. In contrast to IgG, IgM and IgA antibodies have been found to decline more rapidly [94,95].

Serological tests also vary according to the viral antigens measured. Spike proteins $(\mathrm{S})$ and nucleocapsid proteins $(\mathrm{N})$ are the viral antigens used to detect antibodies for SARS-CoV-2. While testing positive for antibodies against either $\mathrm{N}, \mathrm{S}$, or receptor binding domains (RBD) can accurately indicate prior infection [96], recent evidence warns against the extensive use of $\mathrm{N}$ protein-based serology testing for determining potential protective immunity to COVID-19. Research has found that N protein-binding antibodies do not always correlate with the presence of S-RBD neutralizing antibodies [97].

In most cases, infection with SARS-CoV-2 initiates an adaptive antiviral humoral and cellular immune response, including B and T cell-mediated immunity [98-100]. The humoral response includes antibodies against specific viral antigens, such as $\mathrm{N}$ and $\mathrm{S}$ proteins. The S protein comprises two subunits, S1 and S2, the former containing the RBD that mediates the binding of the virus to cells. Evidence suggests that the RBD of $S$ protein is the main target for neutralizing antibodies [99,101-104]. Tests targeting the $S$ protein may provide higher sensitivity and specificity [102]. Serology studies might use the differential reactivity of S- and N-specific antibodies to help distinguish prior infection from vaccination, particularly for vaccines that produce antibodies only against the S protein [87]. Antibodies-including IgM, IgG, and IgA-against the S protein and its subunits can be detected starting at one to three weeks after infection $[94,105]$, and until at least six months post-infection [106]. The sensitivity of these tests is higher from three weeks after symptom onset.

Notably, the neutralization assay, a lab-based test, is the gold standard for determining potential protective immunity, although a correlation with protection has not been established. This test can help (1) to increase understanding of immunity and potentially 
evaluate vaccine efficacy, (2) to determine the real number of infections by enhancing the serological diagnosis of asymptomatic infections, and (3) to identify eligible donors for a possibly beneficial convalescent plasma therapy [89]. Nevertheless, its broad implementation is limited because this test has a higher cost and requires a biosafety level 3 laboratory (a laboratory with permission to culture SARS-CoV-2-infected cells) [96].

An alternative that has received recent attention is the use of pseudovirus neutralization assays. Pseudovirus neutralization assays are a great alterative for highly pathogenic viruses such as SARS-CoV-2. A pseudovirus neutralization assay is a laboratory method used to study the effect of antibodies or drugs in preventing infection. This method uses a vector (pseudovirus) that has a similar conformational structure of the surface proteins and the ability to enter cells using the same mechanisms and receptors to that of the native virus. Pseudoviruses are, however, much safer to handle, since they cannot replicate, requiring only biosafety level 2 laboratories. Pseudovirus neutralization can be automated and standardized in laboratories across the world, as has been done for the human immunodeficiency virus [107].

This method has the potential for improving SARS-CoV-2 immunization policies, by providing an easy and accessible approach to classical serum neutralization assays, that can also easily be adapted to different SARS-CoV-2 variants and maintain a similar sensitivity and quantitative reliability [108]. Several important factors contribute to an effective vaccine response, including the presence of frequent virus mutations, the emergence of new virus strains, different vaccines in the market, and different patient characteristics (such as the use of different drugs and the presence of comorbidities). The use of neutralizing antibodies and indirect anti-RBD/anti-S assays can be useful to customize future approaches. It may also aid in choosing the ideal vaccine for a specific patient and the ideal period for a new shot. The evaluation of the cellular response against SARS-CoV-2 will soon also be available for clinical practice, which may also contribute to future decision-making [109].

Serological tests can be performed through laboratory-based assays and rapid diagnostic tests (RDT). While laboratory-based assays can generate more accurate results and provide qualitative and quantitative data, they have an increased turnaround time, higher cost, and require laboratory capacity [96]. Contrarily, RDTs usually require 15 to $30 \mathrm{~min}$ to process and can easily be implemented in decentralized settings. However, RDTs can only generate qualitative data and have shown wide variability in results. Qualitative data describe the absence or presence of antibodies in the sample, providing a simple answer on whether a person was once infected. Quantitative evidence, obtained through laboratory-based assays, provides more detailed information on the presence and level (or titer) of antibodies in the sample. The choice of tests is particularly important and should be carefully considered, taking into account the purpose of use, the cost, and the testing requirements and capacity in each context. Quantitative data are particularly important for studies aiming to understand the antibody response to natural infection and vaccination and to determine whether a person is eligible to donate convalescent plasma.

\section{Introduction of SARS-CoV-2 Vaccines in Latin America}

The pandemic has triggered a massive effort to develop COVID-19 vaccines in record time. Today, the general public perceives COVID-19 immunization as the most critical means of reducing the burden of disease, hospitalizations, and deaths, contributing to the return of normalcy and economic recovery. Nonetheless, immunization alone might not be sufficient to put a full stop to the pandemic and reach endemic status. Governments introduced COVID-19 vaccines in LATAM countries starting in December 2020. Unlike other regions of the world, countries in LATAM have proceeded independently regarding the procurement of doses and the principles that organize immunization rollout.

Launched in April 2020, COVID-19 Vaccines Global Access (COVAX) is a global platform to support the development, manufacturing, and distribution of COVID-19 vaccines [110,111], providing a procurement mechanism by which the platform purchases vaccines on behalf of countries [112]. By securing favorable purchasing deals, COVAX aims 
to contribute to addressing the unequal global distribution of doses. There are two types of countries participating in the COVAX acquisition program: (1) those in the position to selffinance and (2) those funded by the Gavi COVAX Advance Market Commitment program. While 14 countries in LATAM are self-financed [113,114], five middle- and lower-income countries are funded by COVAX [115].

Either through COVAX or independent agreements, countries in the region had contracted doses from 11 providers so far: AstraZeneca-Oxford, Janssen-Cilag, Moderna, Pfizer-BioNTech, Sputnik V, CanSino BIO, Sinopharm, Sinovac, Covishield, CureVac, and Novavax $[110,116]$. As multiple vaccines have been introduced in the region-diverse in type, manufacturer, and target population-studies evaluating the effectiveness and immune response to the various vaccines are particularly challenging yet necessary.

Given the limited supply of doses worldwide and the logistical challenge to immunize the whole population, countries have proceeded with immunization rollouts prioritizing different population groups. Most countries worldwide, including in LATAM, started vaccinating single groups, such as health care personnel and essential workers, and later proceeded to larger segments of the population based on different vulnerability parameters [117]. The criteria used for prioritization according to national COVID-19 immunization plans varies significantly between countries. As illustrated in Table 2, despite many international organizations advising countries to consider the risk of infection (indicated by a high prevalence of community transmission, for example) when prioritizing population groups, among the focus countries, only Argentina included this criterion in its national immunization plan [118]. In contrast, there is a broad agreement to prioritize based on age, comorbidities, and work/profession depending on higher exposure risk across Argentina [118], Brazil [119], Chile [120], Colombia [121,122], and Mexico [123].

Table 2. Prioritization criteria according to national COVID-19 immunization plans in focus countries.

\begin{tabular}{cccccc}
\hline Prioritization Criteria & Argentina & Brazil & Chile & Colombia & Mexico \\
\hline People at high risk of infection * & $\checkmark$ & & & $\checkmark$ & $\checkmark$ \\
Age (60-70+) & $\checkmark$ & $\checkmark$ & $\checkmark$ & $\checkmark$ & $\checkmark$ \\
People at risk of severe disease ** & $\checkmark$ & $\checkmark$ & $\checkmark$ & $\checkmark$ & $\checkmark$ \\
People in vulnerable conditions & $\checkmark$ & $\checkmark$ & $\checkmark$ & $\checkmark$ \\
Health care workers & $\checkmark$ & $\checkmark$ & $\checkmark$ & $\checkmark$ \\
Essential workers & $\checkmark$ & $\checkmark$ & & $\checkmark$ \\
\hline
\end{tabular}

* People at a higher risk of contracting the disease due to high transmission prevalence in their community. ** People that have a higher risk of developing severe symptoms due to comorbidities or debilitating factors. Source: based on reviewed resources [118-123].

Concerns regarding the safety of vaccines for service users have also accompanied immunization rollout in LATAM. While PAHO has recognized the need to strengthen national regulatory mechanisms to ensure that the introduced vaccines are safe and effective [124], the sense of urgency led many countries to administer vaccines that the WHO and/or national regulatory agencies had not approved for use yet [110]. The fear of contracting COVID-19 has led many people to resort to unauthorized distribution channels to access vaccines. Reports of counterfeit or unauthorized vaccines in circulation have emerged in countries such as Bolivia and Colombia [125]. Several news outlets have also reported on concerns from the general public regarding the motives behind decisionmaking, arguing that certain decisions on immunization policies may be political rather than evidence-driven.

Access disparities between and within countries are another source of concern. From a regional perspective, vaccination campaigns in LATAM have stalled due to unequal global access to vaccines and challenges surrounding vaccine production, distribution, and delivery [124-126], including considerable setbacks in the supply of doses acquired through COVAX [127]. Additionally, governments of many countries in the region must deal with the combination of a rugged terrain and an underdeveloped transport infrastructure, resulting in difficulties in appropriately delivering doses. While this has raised concerns regarding a possible vaccine divide between rural and urban communities [128], 
to this day, there is no clear evidence of this occurring. Furthermore, the decision to prioritize immunization in rural areas, regardless of local disease prevalence, has also been debated [129].

Delayed economic recovery is a particular source of apprehension, as evidence suggests that many LATAM countries will not reach full immunization of the eligible population until 2023 [128]. As of 28 October 2021, Chile is the leading country in the region, with $85 \%$ of its population immunized-76\% fully vaccinated, and $8.3 \%$ partially. Among other focus countries, Brazil has managed to cover $74 \%$ of its population (55\% fully vaccinated and $19 \%$ partially), followed closely by Argentina, with $73 \%$ immunized ( $56 \%$ fully vaccinated and $17 \%$ partially). Finally, Colombia has reached $58 \%$ coverage ( $40 \%$ fully vaccinated and $17 \%$ partially) and Mexico's population is $55 \%$ immunized ( $42 \%$ fully vaccinated and $13 \%$ partially) [130].

\section{Potential Areas of Use of Serology Testing and Seroepidemiological Evidence to Support Immunization Policies}

Using serology tests and seroepidemiological data to support immunization policies and strategies across vaccine-preventable diseases is well-documented [131]. According to these studies, serology tests can provide evidence to support the planning, implementation, and monitoring of immunization policies and conduct post-marketing vaccine effectiveness studies to understand and evaluate the efficacy of the antibody response by different vaccines in the market (Table 3) [131-134].

In the context of post-marketing vaccine surveillance, serology tests have been used to (1) determine the duration of immunity after the primary series, (2) evaluate the need for and timing of booster doses, (3) evaluate dosing strategies, and (4) study the efficacy of vaccines across different population groups for vaccines with well-established correlates of protection [131,133,134].

Finally, stakeholders have also used seroepidemiological data to evaluate the effectiveness of immunization policies. Conducting this type of assessment requires evaluating the impact of immunization campaigns by monitoring population immunity over time. This activity is critical when there are recurrent outbreaks despite high immunization coverage. In the past, serology testing has helped in investigating possible causes of infection resurgence, such as those attributed to changes in vaccination schedule or formulation, and monitor progress towards elimination in due time [131,132].

Since the evidence gathered on the use of serosurveys and seroepidemiological data is limited to vaccine campaigns that target specific population groups, extrapolating these findings must be done carefully. In the current scenario, governments must administer COVID-19 vaccines to broader (if not all) segments of the population; thus, implementing serology testing as a policy within the pandemic should be assessed considering the conditions of each country and the cost-benefits of implementing this strategy in each context. Nonetheless, and as we will see in the next section, serology testing in the current pandemic scenario, could be used by the government to support the monitoring of infection and disease, including the middle- and long-term effects of COVID-19 on patients. Endeavoring to monitor population immunity over time can help researchers to investigate infection outbreaks and evaluate the progress of control measures, such as immunization. This information should be used to inform immunization policies, ensuring that resources are used in the most effective and efficient way. Targeted immunization activities and changes to immunization schedules can help to channel vaccine doses to where they are needed the most. 
Table 3. Potential areas where using serology testing can support immunization activities.

\begin{tabular}{|c|c|c|}
\hline & Areas/Activities for the Possible Use of Serology Testing & $\begin{array}{l}\text { Examples of Use across } \\
\text { Vaccine-Preventable } \\
\text { Diseases }\end{array}$ \\
\hline \multirow{4}{*}{$\begin{array}{l}\text { Post-marketing } \\
\text { surveillance of the efficacy } \\
\text { and duration of protection } \\
\text { of vaccines }\end{array}$} & Determine the duration of immunity after the primary series. & \multirow{3}{*}{$\begin{array}{l}\text { Diphtheria } \\
\text { Hib } \\
\text { Meningococcus } \\
\text { Pertussis } \\
\text { Tetanus }\end{array}$} \\
\hline & & \\
\hline & $\begin{array}{l}\text { Determine the need for and timing of booster doses and evaluate } \\
\text { doses strategy. }\end{array}$ & \\
\hline & Determine the efficacy of a vaccine across populations. & $\begin{array}{l}\text { Pneumonia } \\
\text { HPV }\end{array}$ \\
\hline \multirow{4}{*}{$\begin{array}{l}\text { Immunization policy } \\
\text { planning }\end{array}$} & Estimate burden of disease. & $\begin{array}{l}\text { Hepatitis B } \\
\text { Rubella } \\
\text { Hepatitis A } \\
\text { Measles } \\
\text { Varicella } \\
\text { Yellow fever }\end{array}$ \\
\hline & $\begin{array}{l}\text { Estimate theoretical herd immunity thresholds derived from both } \\
\text { immunization and natural infection. }\end{array}$ & $\begin{array}{l}\text { Hepatitis B } \\
\text { Measles } \\
\text { Rubella } \\
\text { Poliomyelitis }\end{array}$ \\
\hline & $\begin{array}{l}\text { Guide decision-making regarding the need for supplemental } \\
\text { immunization activities and changes to immunization schedules. }\end{array}$ & \multirow{2}{*}{$\begin{array}{l}\text { Measles } \\
\text { Rubella } \\
\text { Poliomyelitis }\end{array}$} \\
\hline & Identify prioritization groups for the first stage of vaccination rollout. & \\
\hline \multirow{7}{*}{$\begin{array}{l}\text { Monitoring effectiveness } \\
\text { of immunization policies } \\
\text { and outbreak vigilance }\end{array}$} & $\begin{array}{l}\text { Monitor population immunity over time, especially useful in the } \\
\text { absence of virus circulation. }\end{array}$ & \multirow{3}{*}{$\begin{array}{l}\text { Hepatitis B } \\
\text { Measles } \\
\text { Rubella } \\
\text { Poliomyelitis } \\
\text { Tetanus }\end{array}$} \\
\hline & Monitor progress towards disease elimination. & \\
\hline & $\begin{array}{l}\text { Identify groups with gaps in immunity and with active transmission to } \\
\text { target immunization campaigns. }\end{array}$ & \\
\hline & Investigate causes of disease resurgence. & \multirow{2}{*}{$\begin{array}{l}\text { Diphtheria } \\
\text { Hib } \\
\text { Meningococcus } \\
\text { Pertussis }\end{array}$} \\
\hline & $\begin{array}{l}\text { Assess the risk of outbreaks and identify high-risk population } \\
\text { subgroups, especially useful in the absence of virus circulation. }\end{array}$ & \\
\hline & $\begin{array}{l}\text { Evaluate the impact of campaigns and effectiveness of immunization } \\
\text { programs, particularly when there are continued outbreaks despite } \\
\text { high reported coverage. }\end{array}$ & $\begin{array}{l}\text { Measles } \\
\text { Rubella } \\
\text { Poliomyelitis }\end{array}$ \\
\hline & $\begin{array}{l}\text { Estimate vaccine coverage, only when there is absence of virus } \\
\text { circulation and reliable record-keeping. }\end{array}$ & $\begin{array}{l}\text { Tetanus (potentially) } \\
\text { Hepatitis B (potentially) }\end{array}$ \\
\hline
\end{tabular}

Source: based on reviewed resources [131-134].

\section{Current Guidelines and Recommendations on the Use of Serology Testing in the Region}

From an international perspective, WHO, PAHO, FDA, and CDC have all provided statements and recommendations on the use of serology testing in the context of the COVID-19 pandemic. WHO has recommended against the use of serology testing for so-called "immunity passports" [135,136]. The use of serology testing has, however, been recognized for surveillance and research purposes [86]. According to WHO's protocols for seroepidemiological studies, the use of serology testing can support five primary objectives: to (1) measure the seroprevalence of antibodies against COVID-19 in the general population to quantify the accumulated immunity, (2) estimate the proportion of pre-symptomatic, asymptomatic and subclinical infections in the population, (3) establish the risk factors for contracting the infection by comparing the exposures of infected and uninfected people, (4) accurately calculate the fatality rate, and (5) help to understand the kinetics of antibodies against COVID-19 better [137]. In alignment, PAHO recommends using serology testing 
for epidemiological investigations and seroprevalence studies, further calling for the use of tests measuring IgG and IgM antibodies [138].

Serology testing can also contribute to accurately forecasting the spread of COVID-19, providing essential evidence for optimal public policy measures. Different frameworks have been proposed for modeling the spread of COVID-19, including compartmental models, differential equation model, and branching point process models. The compartmental model Susceptible Exposed Infectious Removed (SEIR) is currently the most widely used model to forecast epidemic diseases such as COVID-19, despite the fact that it has been found to be less accurate than the Hawkes model (a branching point process model) [139]. Although many factors contribute to this discrepancy, the most significant factor seems to be that SEIR forecasts of future confirmed cases or deaths depend significantly on estimates of the total numbers of asymptomatic or mildly symptomatic cases [140,141], which is challenging to estimate. Most forecasting models require reliable estimates of the proportion of the population that remain susceptible to the disease and the proportion who have contracted the disease and may be, at least temporarily, immune. These particular estimates are difficult to calculate without population-wide testing [142,143]. Given that many COVID-19 cases are mild or showcase no symptoms, serology testing becomes a critical tool to provide accurate estimates, helping forecasting models to be parameterized accurately and obtain more reliable results.

In a statement, the WHO's Director-General, Dr. Tedros Adhanom, recommended conducting seroprevalence studies to help understand the duration of immunity following both natural infection and vaccination and to evaluate the extension of the infection across different population groups [144]. The FDA and CDC are somewhat in agreement with this statement. On the one hand, these institutions recognize that serology tests can help to identify people who may have had a prior SARS-CoV-2 infection and have developed an immune response, aiding efforts to estimate the cumulative incidence of infection (or vaccination) in a community $[87,145,146]$. They also acknowledge that more research is needed to understand the robustness and durability of immunity, particularly following vaccination. However, the FDA and CDC state that the validity of using serology tests for this purpose is still pending [87], even though serology tests were used to evaluate vaccine efficacy during Phase III trials. Therefore, the FDA and CDC recommend against using antibody testing to assess a person's immunity or protection from COVID-19 following vaccination and the need for vaccination in unvaccinated individuals $[87,146]$.

At the regional level, the Argentinian Consensus on the Use of Diagnostic Tests for SARS-CoV-2 [147] recommends implementing seroprevalence studies to assess the evolution of the pandemic and using serology testing to identify possible candidates for donating convalescent plasma for convalescent plasma therapy. The FDA shares this position [145]. Moreover, this consensus stands out by recommending the use of serology testing to conduct retrospective diagnoses of asymptomatic infections or infections that were not detected earlier to identify the association of infection and late complications [147].

When analyzing the countries of focus, it is worth noting that none have included serology testing in their national immunization plans. However, in Argentina [148], Brazil [149], Chile [150], and Mexico [151], serology testing has been recognized and implemented by different research groups to estimate the prevalence of infection, study the immune response to the disease, and identify individuals that might be protected after natural infection or vaccination, among other purposes. As of 20 October 2021, according to the SeroTracker, Brazil, Chile and Mexico have conducted country-/territory-wide serosurveys as well as local studies. In contrast, Argentina has only conducted local serosurveys [152]. Notably, a study on vaccines effectiveness in nearly 60,000 individuals in Chile found that IgG positivity for CoronaVac recipients was considerably lower after the first and the second doses (28\% and 77\%, respectively) than for the Pfizer-BioNTech's mRNA BNT162b2 vaccine recipients, which record a seropositivity of $80 \%$ after the first dose and $95 \%$ after the second dose. This study supports the argument that monitoring seropositivity over time can provide data to reassess future vaccination rollout strategies [153]. 
Finally, while Argentina [154] and Colombia [155] have followed the recommendation provided by international guidelines against the use of serology testing to diagnose acute infection $[87,138,145,146,156]$, Brazil recognizes the use of serology tests as an auxiliary diagnosis tool [149].

\section{Challenges and Barriers to the Use of Serology Testing to Support Immunization Policies in Latin America and the World}

Several international organizations and the academic community have voiced their concerns regarding the challenges and barriers to the use of serology testing in the context of immunization policies and the broader response to the COVID-19 pandemic. These challenges can be categorized into two main groups. The first group includes the intrinsic limitations of serology testing. The second group points to the challenges surrounding the use of serology testing in the context of immunization policies, surveillance and monitoring activities, and epidemiology studies.

\subsection{Challenges Related to the Limitations of Serology Testing}

Some researchers observed considerable variations in the results of SARS-CoV-2 seroprevalence studies. Studies may underestimate the prevalence of SARS-CoV-2 for several reasons. The first and perhaps more apparent reason results from the choice of assay [157]. Not only do the sensitivity and specificity of serology tests vary between manufacturers [158], but variations in test performance can be observed depending on the choice of antibodies and antigens measured [157], the type of assay and viral protein measured, the type of sample (blood or plasma) used, and the sample collection process [149]. Another issue is the use of quantitative versus qualitative tests. The former can provide more space to detect low-level antibodies, which the latter may not. Moreover, the difficulty in detecting mild or asymptomatic cases, resulting in missed community cases and several demographic factors such as age, sex, and ethnicity, may influence test calibration [157].

Cross-reactivity has been a source of concern regarding the use of certain serology tests in prevalence studies [149]. While emerging evidence suggests that cross-reactivity is low to other coronaviruses and influenza A and B [159-162], further studies are needed to determine whether these results will persist through longitudinally collected serum samples and to confirm that emerging SARS-CoV-2 variants, especially those affecting the $S$ protein, will not result in changes in cross-reactivity $[160,163]$.

Finally, while the use of serologic testing to identify, evaluate and understand the immune response from natural infection is well accepted, many argue that serology tests are not entirely validated to assess the level of protection provided by COVID-19 vaccination $[87,146]$. Moreover, since only a few serology tests can distinguish between the antibody response triggered from natural infection and vaccination [147], the use of serology testing to evaluate COVID-19 vaccine-induced immunity remains a contested idea.

\subsection{Challenges Related to the Use of Serology Testing to Support Immunization Policies and Estimate Epidemiological Variables}

Using serology testing to support immunization policies is primarily limited by gaps in the knowledge and understanding of (1) the immune response triggered by infection and vaccination and (2) the subsequently conferred immunity. How long antibodies against SARS-CoV-2 persist in the body, the titers of protection and the conditions that lead to protection remain unknown. While some studies indicate that IgG antibodies, including IgG against the $\mathrm{S}$ and $\mathrm{N}$ proteins, persist for at least nine to ten months after infection in most cases [106], other studies have reported an absence of IgG antibodies following infection in approximately $5-10 \%$ of cases $[164,165]$. Moreover, since antibody persistence has been noted to vary between assays, our understanding of the antibody response may be limited by the choice of tests [166]. Notably, the conditions that lead to protection and reinfection, including the roles of humoral and cellular immune responses, also remain unclear. Nevertheless, recent evidence indicates that previous infection leads 
to a substantially reduced risk of reinfection in the following six to seven months after infection [167-170].

Determining if infection or vaccination confers an antibody response that grants immunity essentially depends on whether correlates of protection are available. A correlate of protection is an immunological measurement (an immune marker) used to predict protection against disease or infection reliably [171,172]. Determining correlates of protection may be challenged by recorded differences in the antibody response found across immunecompetent populations. Studies have documented, for example, that patients who had experienced more severe symptoms had also developed a more robust antibody response, exhibiting higher titers and longer persistence of $\operatorname{IgM}, \operatorname{IgG}$, and $\operatorname{IgA}$ antibodies $[173,174]$. Studies have also reported discrepancies in reinfection rates related to age group. While a study conducted on young males found that previous infection reduces the incidence rate of reinfection by $82 \%$ [175], another documented a reduction of only $47.1 \%$ among adults aged 65 years and older [168]. Sound correlates of protection will have to account for differences of this nature.

Nonetheless, in recent months, significant evidence has been developed on correlates of protection. Although there are documented cases of reinfection [176,177], several studies indicate that individuals who have SARS-CoV-2 antibodies are less likely to experience reinfection than individuals who do not have such antibodies [167,170,178-182]. Some studies suggest that previous infection may reduce the risk of reinfection by $80 \%$ to $84 \%[167,168]$, and that lower SARS-CoV-2 IgG titers (or their absence) and lower levels of neutralizing antibodies may correlate with a higher risk of reinfection [175]. Notably, a recent study using data from 171 cases of SARS-CoV-2 infection and 1404 non-cases demonstrated that higher anti-spike IgG, anti-RBD IgG, and neutralizing antibody titers are all associated with a lower risk of symptomatic disease. However, the same study also found that none of the serological measurements showed a correlation with protection against asymptomatic infection or symptomatic illness with mild upper respiratory symptoms [183], further confirming the observation that infection remains possible in fully vaccinated individuals, despite high effectiveness against more severe forms of the disease (such as those causing hospitalization or death) as reported by COVID-19 vaccine clinical trials and real-world evidence from vaccine rollout programs [76,184-194]. According to the results of this study, there is no single threshold value indicative of protective immunity. Instead, there is a decrease and increase in the probability of infection relative to a higher and lower immune response, respectively [183]. Feng et al. (2021) instead provided antibody estimates that correspond with $50 \%$ to $90 \%$ vaccine efficacies.

While evidence of this nature supports the argument that post-immunization antibody levels might be used as the basis for a correlate of protection, the necessary next steps toward achieving consensus on this measurement include: (1) establishing comparable antibody measurements across laboratories, (2) agreeing on a neutralization assay to serve as the gold standard, (3) calculating, where possible, the protective threshold in Phase III studies, (4) convening stakeholders to reach a consensus despite discrepancies between studies, and (5) verifying that the correlate of protection will apply to new variants using appropriately adapted assays [195].

Given the discrepancies in the antibody response across populations, the absence of consensus on clinical markers of correlation, and the lack of knowledge of the impact of emerging variants on immunity, additional studies are required to provide sound correlates of protection. There is a strong need for standardized processes and more extensive longitudinal and multicenter studies that include different population groups. Efforts to address knowledge gaps should emphasize the adequacy of the study design and its standardized implementation to ensure the comparability of data across countries. While the WHO has taken the first steps to standardize the different assays available in the market by suggesting the use of a single measurement unit $(\mathrm{BAU} / \mathrm{mL})$, urging different in vitro diagnostic companies to standardize their assays [196], there is also an imperative need to translate current evidence into recommendations and guidelines addressing the 
strengths and weaknesses of tests in this evolving scenario. Considering the financial constraints faced by many LATAM countries, stakeholders from the private and public sectors should invest to ensure the availability of adequate human and technological capacity to implement these studies. As new evidence becomes available, international organizations, professional societies and the academic community should help to translate this evidence into sound recommendations to ensure decisions on the use of serology testing are based on the best available evidence, across the different stages of immunization. The absence of guidelines poses a risk to the safety of service users and increases concerns about inequalities. In the absence of guidelines, only those in a position of financial and expertise privilege will be able to effectively use serology tests.

Once correlates of protection are available, in partnership with research institutes, governments could conduct serosurveys on vaccinated individuals from specific population groups and the general public to determine the duration of immunity and the need and timing of booster doses. In addition, serosurveys could help us to assess the effectiveness of different vaccine formulations as they become available and are being introduced in different epidemiological scenarios, including those with new virus variants. The implementation of serosurveys to evaluate and monitor vaccine effectiveness should be considered as a complementary tool to infection studies and carefully considering the prevalence of infection in the community when interpreting data.

Besides the presented knowledge gaps, implementing serosurveys also faces challenges related to time, technology, logistical, and financial constraints [131]. These challenges may limit the use of serology testing to targeted activities rather than broad policies. Serosurvey implementation requires (1) integration between clinical, laboratory, and epidemiology aspects, (2) appropriate study design and optimal sample size, (3) adequate laboratory capacity, (4) appropriate laboratory methods, and (5) standardized and validated procedures $[132,147,197]$. Considering the financial constraints faced by many LATAM countries, public-private partnerships may become an essential piece of the puzzle, as these would allow higher investment in capacity and resources to implement these studies. It is worth noting that the choice of serology test is key to ensuring the validity of results, comparability, and integration of data across studies and countries. Evidence points to serology tests measuring IgG antibodies against S-RBD as the best available to inform SARS-CoV-2 vaccine-associated immunity [198-200], yet many commercially available kits detect binding antibodies against the $\mathrm{N}$ protein. While these tests may not be the best alternative to evaluate vaccine-induced immunity, they may still be used to detect prior exposure to the virus [97]. Manufacturers must ensure that tests' properties are clearly disclaimed, so that service users and researchers can select a test according to the purpose of use.

Finally, as multiple vaccines, diverse in both manufacturer and type, are currently being introduced to individuals who may or may not have had prior infection, studying and evaluating antibody production and vaccine-induced immunity becomes exceptionally complicated. Research institutes and the academic community must pay particular attention to studies that can help to identify and understand potential differences in the kinetics of the immune response and antibody dynamics against SARS-CoV-2 and vaccination.

\section{Conclusions}

Evidence and current national and international guidelines and recommendations highlight the potential benefits of using serology testing as a strategy to support COVID-19 immunization policies and the broader policy response to the pandemic. Serology tests have successfully helped to develop evidence and provide critical information for decisionmaking in the past. While considerable financial and logistical constraints characterize the current scenario, the benefits of using serology testing might outweigh the medium- to long-term costs.

Serology tests are a valuable tool to help us understand the antibody response triggered by natural infection and vaccines, as well as to provide the necessary evidence to 
design better and more effective immunization policies. With a concerning shortage of vaccines in many LATAM countries and the widely accepted notion that immunization is vital for the control of the pandemic and the return to normalcy, information that can contribute to implementing effective immunization strategies is particularly critical to safeguard the economic recovery of countries and prevent soaring inequalities in the region.

Nevertheless, the full use of serology tests in this context requires developing the necessary evidence to address critical knowledge gaps. For this purpose, the commitment and collaboration of both private and public stakeholders and the academic and international communities are of utmost importance.

Author Contributions: All authors contributed equally to this work. C.E.d.S.F., H.G.-D., N.C.J.B., E.L. and M.O. served as experts during the three online panel sessions. All authors have read and agreed to the published version of the manuscript.

Funding: The authors disclose receipt of financial support from Abbott Laboratories for the research, authorship, and publication of this article. The authors independently drafted the manuscript's contents and recommendations, and this manuscript is their product.

Institutional Review Board Statement: Not applicable.

Informed Consent Statement: Not applicable.

Data Availability Statement: Not applicable.

Conflicts of Interest: Abbott Laboratories funded the online panel sessions held to develop this final document. The funders sponsored a third-party consulting agency, Policy Wisdom LLC, to facilitate the sessions and coordinate the development of this document but had no role in the agenda of the meetings nor the design and drafting of the review. The recommendations are based on a review of the literature, publicly available evidence, and subsequent expert deliberations. The views expressed in this document are exclusively those of the authors and are not influenced by any external parties or sponsors.

\section{References}

1. Bonanni, P.; Cantón, R.; Gill, D.; Halfon, P.; Liebert, U.G.; Crespo, K.A.N.; Martín, J.J.P.; Trombetta, C.M. The Role of Serology Testing to Strengthen Vaccination Initiatives and Policies for COVID-19 in Europe. COVID 2021, 1, 20-38. [CrossRef]

2. Listings of WHO's Response to COVID-19. Available online: https://www.who.int/news/item/29-06-2020-covidtimeline (accessed on 7 July 2021).

3. La Expansión del COVID-19 en América Latina. Available online: https://redemc.net/campus/la-expansion-del-covid-19-enamerica-Latina (accessed on 7 July 2021).

4. WHO Coronavirus (COVID-19) Dashboard, Update 24 September 2021. Available online: https:// covid19.who.int/ (accessed on 26 September 2021).

5. World Health Organization. COVID-19 Weekly Epidemiological Update, 63rd ed.; World Health Organization: Geneva, Switzerland, 2021; pp. 1-20. Available online: https://www.who.int/publications/m/item/weekly-epidemiological-update-on-covid-19---2 6-october-2021 (accessed on 28 October 2021).

6. Inter-American Development Bank. COVID-19: Situation Update in Latin America and the Caribbean; Update 28 October 2021; Inter-American Development Bank: Washington, DC, USA, 2021. Available online: https://www.iadb.org/en/coronavirus/ current-situation-pandemic (accessed on 28 October 2021).

7. Johns Hopkins University \& Medicine Coronavirus Resource Center: Mortality Analysis. Available online: https://coronavirus. jhu.edu/data/mortality (accessed on 28 October 2021).

8. Reporta Ssa 493 Mil Muertes en Exceso. Available online: https://www.reforma.com/aplicacioneslibre/preacceso/articulo/ default.aspx?_rval=1\&urlredirect=https: / / www.reforma.com/reporta-ssa-493-mil-muertes-en-exceso/ar2212943?utm_ source=bcm_nl_coronavirus_reforma\&utm_medium=email\&utm_campaign=nl_coronavirus_reforma_20210701\&utm_term = usr_registrado (accessed on 11 July 2021).

9. Palacio Mejía, L.S.; Wheatley Fernández, J.L.; Ordoñez Hernández, I.; López Ridaura, R.; Lopez-Gatell Ramirez, H.; Hernandez Avila, M.; Hernández Ávila, J.E. Estimación del Exceso de Mortalidad por Todas las Causas Durante la Pandemia del COVID-19 en México. Salud Publica de Mexico 2021, 63, 211-224. [CrossRef]

10. European Centre for Disease Prevention and Control. Data on 14-Day Notification Rate of New COVID-19 Cases and Deaths; European Centre for Disease Prevention and Control: Stockholm, Sweden, 2021. Available online: https://www.ecdc.europa.eu/en/ publications-data / data-national-14-day-notification-rate-covid-19 (accessed on 28 October 2021). 
11. Organization for Economic Co-operation and Development. COVID-19 in Latin America and the Caribbean: An Overview of Government Responses to the Crisis; Updated 11 November 2020; Organization for Economic Co-operation and Development: Paris, France, 2020; pp. 1-30. Available online: https:/ / read.oecd-ilibrary.org/view / ?ref=129_129907-eae84sciov\&title=COVID-19-inLatin-Amercia-and-the-Caribbean_An-overview-of-government-responses-to-the-crisis (accessed on 24 June 2021).

12. Organization for Economic Co-operation and Development Hospital Beds (Indicator). Available online: https://www.oecdilibrary.org/social-issues-migration-health/hospital-beds/indicator/english_0191328e-en (accessed on 4 May 2021).

13. Gronvall, G.; Connell, N.; Kobokovich, A.; West, R.; Warmbrod, K.L.; Shearer, M.; Inglesby, T. Developing a National Strategy for Serology (Antibody Testing) in the United States; The Johns Hopkins Center for Health Security: Baltimore, MD, USA, 2020; pp. 1-29. Available online: https:/ / www.centerforhealthsecurity.org/our-work/pubs_archive/pubs-pdfs/2020/200422-nationalstrategyserology.pdf (accessed on 11 July 2021).

14. Pan-American Health Organization. Rapid Assessment of Service Delivery for NCDs During the COVID-19 Pandemic in the Americas; Pan-American Health Organization: Washington, DC, USA, 2020; pp. 1-8. Available online: https://iris.paho.org/bitstream/ handle/10665.2/52250/PAHONMHNVCOVID-19200024_eng.pdf?sequence=6\&isAllowed= (accessed on 4 May 2021).

15. Hamblin, M. Is Everyone Depressed? The Atlantic. Available online: https://www.theatlantic.com/health/archive/2020/05/ depression-coronavirus/611986 (accessed on 11 July 2021).

16. Substantial Investment Needed to Avert Mental Health Crisis. Available online: https://www.who.int/newsroom/detail/14-052020-substantial-investment-needed-to-avert-mental-health-crisis (accessed on 11 July 2021).

17. United Nations. Policy Brief: COVID-19 and the Need for Action on Mental Health; United Nations: New York, NY, USA, 2020; pp. 1-17. Available online: https://www.un.org/sites/un2.un.org/files/un_policy_brief-covid_and_mental_health_final.pdf (accessed on 4 May 2021).

18. The Impact of COVID-19 on the Mental Health of Adolescents and Youth. Available online: https://www.unicef.org/lac/en/ impact-covid-19-mental-health-adolescents-and-youth (accessed on 4 May 2021).

19. World Health Organization. Maintaining Essential Health Services: Operational Guidance for the COVID-19 Context Interim Guidance, 1 June 2020; World Health Organization: Geneva, Switzerland, 2020; pp. 1-57. Available online: https://www.who.int/ publications/i/item/WHO-2019-nCoV-essential-health-services-2020.1 (accessed on 11 July 2021).

20. Causey, K.; Fullman, N.; Sorensen, R.J.D.; Galles, N.C.; Zheng, P.; Aravkin, A.; Danovaro-Holliday, M.C.; Martinez-Piedra, R.; Sodha, S.V.; Velandia-González, M.P.; et al. Estimating Global and Regional Disruptions to Routine Childhood Vaccine Coverage during the COVID-19 Pandemic in 2020: A Modelling Study. Lancet 2021, 398, 522-534. [CrossRef]

21. El Encierro Imposible de América Latina: Cuando la Cuarentena es un Lujo, 2 September 2020. Available online: https:// forbescentroamerica.com/2020/09/02/el-encierro-imposible-de-america-latina-cuando-la-cuarentena-es-un-lujo/ (accessed on 26 September 2021).

22. Benítez, M.A.; Velasco, C.; Sequeira, A.R.; Henríquez, J.; Menezes, F.M.; Paolucci, F. Responses to COVID-19 in Five Latin American Countries. Health Policy Technol. 2020, 9, 525-559. [CrossRef] [PubMed]

23. Sullivan, M.P.; Beittel, J.S.; Meyer, P.J.; Seelke, C.R.; Taft-Morales, M. Latin America and the Caribbean: Impact of COVID-19; Report No. IF11581; Congressional Research Service: Washington, DC, USA, 2021; pp. 1-3. Available online: https://fas.org/sgp/crs/ row /IF11581.pdf (accessed on 24 June 2021).

24. Basto-Aguirre, N.; Nieto-Parra, S.; Vázquez-Zamora, J. Informality in Latin America in the Post COVID-19 Era: Towards a More Formal "New Normal"? The Latin American and Caribbean Economic Association: Bogotá, Colombia, 2020. Available online: http:/ / www.lacea.org/vox/?q=blog/informality_latam_postcovid19 (accessed on 4 May 2021).

25. Oxfam Llama a los Gobiernos de América Latina a Actuar Para Evitar la Profundización de la Desigualdad Ante la Crisis por COVID-19. Available online: https: / / www.oxfam.org/en/node/12128 (accessed on 4 May 2021).

26. ECLAC Contraction of Economic Activity in the Region Intensifies Due to the Pandemic: It Will Fall -9.1\% in 2020. Available online: https: / / www.cepal.org/en/pressreleases/contraction-economic-activity-region-intensifies-due-pandemic-it-will-fall91-2020 (accessed on 4 May 2021).

27. Economic Commission for Latin America and the Caribbean. Care in Latin America and the Caribbean During the COVID-19: Towards Comprehensive Systems to Strengthen Response and Recovery; Brief v 1.1. 19.08.2020; Economic Commission for Latin America and the Caribbean: Santiago, Chile, 2020; pp. 1-23. Available online: https://repositorio.cepal.org/bitstream/handle/11362/45917/ 190820_en.pdf (accessed on 4 May 2021).

28. Economic Commission for Latin America and the Caribbean. Education in the Time of COVID-19; Economic Commission for Latin America and the Caribbean: Santiago, Chile, 2020; pp. 1-20. Available online: https://repositorio.cepal.org/bitstream/handle/ 11362/45905/1/S2000509_en.pdf (accessed on 4 May 2021).

29. Growth of Domestic Violence and Sexual Abuse Reports during the COVID-19 Lockdown in Selected Latin American Countries as of April 2020. Available online: https:/ / www.statista.com/statistics/1113975/gender-violence-growth-coronavirus-latinamerica / (accessed on 4 May 2021).

30. COVID-19 Educational Disruption and Response. Available online: https://en.unesco.org/news/covid-19-educationaldisruption-and-response (accessed on 4 May 2021).

31. United Nations Educational, Scientific and Cultural Organization. Education: From Disruption to Recovery. COVID-19 Impact on Education; UNESCO Institute for Statistics Data: Paris, France, 2021. Available online: https://en.unesco.org/covid19/ educationresponse (accessed on 4 May 2021). 
32. Bitler, M.P.; Hoynes, H.W.; Schanzenbach, D.W. The Social Safety Net in the Wake of COVID-19. Brookings Pap. Econ. Act. 2020, 2020(2), 119-158. [CrossRef]

33. University of Oxford, Blavatnik School of Government. Codebook for the Oxford Covid-19 Government Response Tracker; Codebook Version 3.3; University of Oxford: Oxford, UK, 2020. Available online: https://github.com/OxCGRT/covid-policy-tracker/blob/ master/documentation/codebook.md (accessed on 28 June 2021).

34. COVID-19 Government Response Tracker. Available online: https://www.bsg.ox.ac.uk/research/research-projects/oxfordcovid-19-government-response-tracker (accessed on 14 July 2021).

35. Nicola, M.; Alsafi, Z.; Sohrabi, C.; Kerwan, A.; Al-Jabir, A.; Iosifidis, C.; Agha, M.; Agha, R. The Socio-Economic Implications of the Coronavirus Pandemic (COVID-19): A Review. Int. J. Surg. 2020, 78, 185-193. [CrossRef] [PubMed]

36. Organization for Economic Co-operation and Development. OECD Policy Responses to Coronavirus (COVID-19) COVID-19 in Latin America and the Caribbean: Regional Socio-Economic Implications and Policy Priorities; Organization for Economic Co-operation and Development: Paris, France, 2020; pp. 1-19. Available online: https://read.oecd-ilibrary.org/view/?ref=129_129904-k3xp1 7fqbl\&title=COVID-19-in-Latin-America-and-the-Caribbean-Regional-socio-economic-implications-and-policy-priorities\& _ga=2.227406621.1458094030.1625999062-1780823184.1624552003 (accessed on 7 July 2021).

37. Salazar, L.; Muñoz, G. Ensuring Food Security in LAC in the Context Of Covid, Challenges and Interventions; Inter-American Development Bank: New York, NY, USA, 2020; pp. 1-22. Available online: https://publications.iadb.org/publications/english/document/ Ensuring-Food-Security-in-LAC-in-the-Context-of-Covid-19-Challenges-and-Interventions.pdf (accessed on 7 July 2021).

38. The Coronavirus in Latin America. Available online: https://www.as-coa.org/articles/where-coronavirus-latin-america (accessed on 4 May 2021).

39. Economic Commission for Latin America and the Caribbean. Addressing the Growing Impact of COVID-19 with a View to Reactivation with Equality: New Projections; Especial Report Nr; Economic Commission for Latin America and the Caribbean: Santiago, Chile, 2020; pp. 1-24. Available online: https:/ / repositorio.cepal.org/bitstream/handle/11362/45784/4/S2000470_en.pdf (accessed on 4 May 2021).

40. Davies, N.G.; Abbott, S.; Barnard, R.C.; Jarvis, C.I.; Kucharski, A.J.; Munday, J.D.; Pearson, C.A.B.; Russell, T.W.; Tully, D.C.; Washburne, A.D.; et al. Estimated Transmissibility and Impact of SARS-CoV-2 Lineage B.1.1.7 in England. Science 2021, 372, eabg3055. [CrossRef]

41. Buchan, S.A.; Tibebu, S.; Daneman, N.; Whelan, M.; Vanniyasingam, T.; Murti, M.; Brown, K.A. Increased Household Secondary Attacks Rates With Variant of Concern Severe Acute Respiratory Syndrome Coronavirus 2 Index Cases. Clin. Infect. Dis. 2021, ciab496. [CrossRef]

42. Tegally, H.; Wilkinson, E.; Giovanetti, M.; Iranzadeh, A.; Fonseca, V.; Giandhari, J.; Doolabh, D.; Pillay, S.; San, E.J.; Msomi, N.; et al. Detection of a SARS-CoV-2 Variant of Concern in South Africa. Nature 2021, 592, 438-443. [CrossRef] [PubMed]

43. Faria, N.R.; Mellan, T.A.; Whittaker, C.; Claro, I.M.; Candido, D.D.S.; Mishra, S.; Crispim, M.A.E.; Sales, F.C.S.; Hawryluk, I.; McCrone, J.T.; et al. Genomics and Epidemiology of the P.1 SARS-CoV-2 Lineage in Manaus, Brazil. Science 2021, 372, 815-821. [CrossRef] [PubMed]

44. Curran, J.; Dol, J.; Boulos, L.; Somerville, M.; McCulloch, H.; Macdonald, M.; Leblanc, J.; Curran, J. Transmission Characteristics of SARS-CoV-2 Variants of Concern Rapid Scoping Review. medRxiv 2021. [CrossRef]

45. Public Health England. SARS-CoV-2 Variants of Concern and Variants Under Investigation in England; Technical Briefing 16; Public Health England: London, UK, 2021; pp. 1-71. Available online: https://assets.publishing.service.gov.uk/government/ uploads/system/uploads/attachment_data/file/1001359/Variants_of_Concern_VOC_Technical_Briefing_16.pdf (accessed on 10 August 2021).

46. Campbell, F.; Archer, B.; Laurenson-Schafer, H.; Jinnai, Y.; Konings, F.; Batra, N.; Pavlin, B.; Vandemaele, K.; Van Kerkhove, M.D.; Jombart, T; et al. Increased transmissibility and global spread of SARS-CoV-2 variants of concern as at June 2021. Eurosurveillance 2021, 26, 2100509. [CrossRef] [PubMed]

47. Cherian, S.; Potdar, V.; Jadhav, S.; Yadav, P.; Gupta, N.; Das, M.; Rakshit, P.; Singh, S.; Abraham, P.; Panda, S. Sars-Cov-2 Spike Mutations, L452r, T478k, E484q and P681r, in the Second Wave of Covid-19 in Maharashtra, India. Microorganisms 2021, $9,1542$. [CrossRef] [PubMed]

48. Kang, M.; Xin, H.; Yuan, J.; Ali, S.T.; Liang, Z.; Zhang, J.; Hu, T.; Lau, E.H.Y.; Zhang, Y.; Zhang, M.; et al. Transmission Dynamics and Epidemiological Characteristics of Delta Variant Infections in China. medRxiv 2021. [CrossRef]

49. Teyssou, E.; Delagrèverie, H.; Visseaux, B.; Lambert-Niclot, S.; Brichler, S.; Ferre, V.; Marot, S.; Jary, A.; Todesco, E.; Schnuriger, A.; et al. The Delta SARS-CoV-2 Variant Has a Higher Viral Load than the Beta and the Historical Variants in Nasopharyngeal Samples from Newly Diagnosed COVID-19 Patients. J. Infect. 2021, 83, e1-e3. [CrossRef] [PubMed]

50. McAlister, F.A.; Nabipoor, M.; Chum, A.; Lee, D.S.; Saxinger, L.; Bakal, J.A. Lessons from the COVID-19 Third Wave in Canada: The Impact of Variants of Concern and Shifting Demographics. medRxiv 2021. [CrossRef]

51. Bager, P.; Wohlfahrt, J.; Fonager, J.; Rasmussen, M.; Albertsen, M.; Michaelsen, T.Y.; Møller, C.H.; Ethelberg, S.; Legarth, R.; Button, M.S.F.; et al. Risk of Hospitalisation Associated with Infection with SARS-CoV-2 Lineage B.1.1.7 in Denmark: An Observational Cohort Study. Lancet Infect. Dis. 2021, 21, 1507-1517. [CrossRef] 
52. Public Health England. SARS-Cov-2 Variants of Concern and Variants Under Investigation Technical Briefing 18, 9 July 2021; Public Health England: London, UK, 2020; pp. 1-56. Available online: https://assets.publishing.service.gov.uk/government/ uploads/system/uploads/attachment_data/file/1001358/Variants_of_Concern_VOC_Technical_Briefing_18.pdf (accessed on 2 August 2021).

53. Fisman, D.N.; Tuite, A.R. Progressive Increase in Virulence of Novel SARS-CoV-2 Variants in Ontario, Canada. medRxiv 2021. [CrossRef]

54. Funk, T.; Pharris, A.; Spiteri, G.; Bundle, N.; Melidou, A.; Carr, M.; Gonzalez, G.; Garcia-Leon, A.; Crispie, F.; O'Connor, L.; et al. Characteristics of SARS-CoV-2 variants of concern B. 1.1. 7, B. 1.351 or P. 1: Data from seven EU/EEA countries, weeks $38 / 2020$ to 10/2021. Eurosurveillance 2021, 26, 2100348. [CrossRef]

55. Twohig, K.A.; Nyberg, T.; Zaidi, A.; Thelwall, S.; Sinnathamby, M.A.; Aliabadi, S.; Seaman, S.R.; Harris, R.J.; Hope, R.; LopezBernal, J.; et al. Hospital Admission and Emergency Care Attendance Risk for SARS-CoV-2 Delta (B.1.617.2) Compared with Alpha (B.1.1.7) Variants of Concern: A Cohort Study. Lancet Infect. Dis. 2021. [CrossRef]

56. Paredes, M.I.; Lunn, S.M.; Famulare, M.; Frisbie, L.A.; Painter, I.; Burstein, R.; Roychoudhury, P.; Xie, H.; Mohamed Bakhash, S.A.; Perez, R.; et al. Associations between SARS-CoV-2 Variants and Risk of COVID-19 Hospitalization among Confirmed Cases in Washington State: A Retrospective Cohort Study. medRxiv 2021. [CrossRef]

57. Pearson, C.A.; Russell, T.W.; Davies, N.G.; Kucharski, A.J.; Edmunds, W.J.; Eggo, R.M.; CMMID COVID-19 Working Group. Estimates of Severity and Transmissibility of Novel South Africa SARS-CoV-2 Variant 501Y.V2. Centre for Mathematical Modelling of Infectious Diseases Preprint 2021, 50. Available online: https:/ / cmmid.github.io/topics/covid19/reports/sa-novel-variant/ 2021_01_11_Transmissibility_and_severity_of_501Y_V2_in_SA.pdf (accessed on 2 August 2021).

58. Jassat, W.; Mudara, C.; Ozougwu, L.; Tempia, S.; Blumberg, L.; Davies, M.-A.; Pillay, Y.; Carter, T.; Wolmarans, M.; Von Gottberg, A.; et al. Increased Mortality among Individuals Hospitalised with COVID-19 during the Second Wave in South Africa. medRxiv 2021. [CrossRef]

59. Horby, P.; Huntley, C.; Davies, N.; Edmunds, G.; Ferguson, N.; Medley, G.; Semple, C. NERVTAG Paper on COVID-19 Variant of Concern B.1.1.7; Department of Health and Social Care, Scientific Advisory Group for Emergencies: London, UK, 21 January 2021; pp. 1-9. Available online: https://www.gov.uk/government/publications/nervtag-paper-on-covid-19-variant-of-concern-b117 (accessed on 2 August 2021).

60. Davies, N.G.; Jarvis, C.I.; van Zandvoort, K.; Clifford, S.; Sun, F.Y.; Funk, S.; Medley, G.; Jafari, Y.; Meakin, S.R.; Lowe, R.; et al. Increased Mortality in Community-Tested Cases of SARS-CoV-2 Lineage B.1.1.7. Nature 2021, 593, 270-274. [CrossRef] [PubMed]

61. Sheikh, A.; McMenamin, J.; Taylor, B.; Robertson, C. SARS-CoV-2 Delta VOC in Scotland: Demographics, Risk of Hospital Admission, and Vaccine Effectiveness. Lancet 2021, 397, 2461-2462. [CrossRef]

62. Eyre, D.W.; Taylor, D.; Purver, M.; Chapman, D.; Fowler, T.; Pouwels, K.; Walker, A.S.; Peto, T.E.A. The Impact of SARS-CoV-2 Vaccination on Alpha and Delta Variant Transmission. medRxiv 2021. [CrossRef]

63. Wibmer, C.K.; Ayres, F.; Hermanus, T.; Madzivhandila, M.; Kgagudi, P.; Oosthuysen, B.; Lambson, B.E.; de Oliveira, T.; Vermeulen, M.; van der Berg, K.; et al. SARS-CoV-2 501Y.V2 Escapes Neutralization by South African COVID-19 Donor Plasma. Nat. Med. 2021, 27, 622-625. [CrossRef] [PubMed]

64. Li, R.; Ma, X.; Deng, J.; Chen, Q.; Liu, W.; Peng, Z.; Qiao, Y.; Lin, Y.; He, X.; Zhang, H. Differential Efficiencies to Neutralize the Novel Mutants B.1.1.7 and 501Y.V2 by Collected Sera from Convalescent COVID-19 Patients and RBD Nanoparticle-Vaccinated Rhesus Macaques. Cell. Mol. Immunol. 2021, 18, 1058-1060. [CrossRef] [PubMed]

65. Cele, S.; Gazy, I.; Jackson, L.; Hwa, S.H.; Tegally, H.; Lustig, G.; Giandhari, J.; Pillay, S.; Wilkinson, E.; Naidoo, Y.; et al. Escape of SARS-CoV-2 501Y.V2 from Neutralization by Convalescent Plasma. Nature 2021, 593, 142-146. [CrossRef] [PubMed]

66. Caniels, T.G.; Bontjer, I.; van der Straten, K.; Poniman, M.; Burger, J.A.; Appelman, B.; Lavell, A.H.A.; Oomen, M.; Godeke, G.-J.; Valle, C.; et al. Emerging SARS-CoV-2 Variants of Concern Evade Humoral Immune Responses from Infection and Vaccination. Sci. Adv. 2021, 7, eabj5365. [CrossRef]

67. Planas, D.; Veyer, D.; Baidaliuk, A.; Staropoli, I.; Guivel-Benhassine, F.; Rajah, M.M.; Planchais, C.; Porrot, F.; Robillard, N.; Puech, J.; et al. Reduced Sensitivity of Infectious SARS-CoV-2 Variant B.1.617.2 to Monoclonal Antibodies and Sera from Convalescent and Vaccinated Individuals. bioRxiv 2021. [CrossRef]

68. Sabino, E.C.; Buss, L.F.; Carvalho, M.P.S.; Prete, C.A.; Crispim, M.A.E.; Fraiji, N.A.; Pereira, R.H.M.; Parag, K.V.; da Silva Peixoto, P.; Kraemer, M.U.G.; et al. Resurgence of COVID-19 in Manaus, Brazil, despite High Seroprevalence. Lancet 2021, 397, $452-455$. [CrossRef]

69. Naveca, F.; Nascimento, V.; Souza, V.; Corado, A.; Nascimento, F.; Silva, G.; Costa, Á.; Duarte, D.; Pessoa, K.; Brandão, M.J.; et al. Phylogenetic Relationship of SARS-CoV-2 Sequences from Amazonas with Emerging Brazilian Variants Harboring Mutations E484K and N501Y in the Spike Protein. Virological.org 2021. Available online: https://virological.org/t/phylogeneticrelationship-of-sars-cov-2-sequences-from-amazonas-with-emerging-brazilian-variants-harboring-mutations-e484k-and-n5 01y-in-the-spike-protein/585 (accessed on 2 August 2021).

70. Muik, A.; Wallisch, A.K.; Sänger, B.; Swanson, K.A.; Mühl, J.; Chen, W.; Cai, H.; Maurus, D.; Sarkar, R.; Türeci, Ö.; et al. Neutralization of SARS-CoV-2 Lineage B.1.1.7 Pseudovirus by BNT162b2 Vaccine-Elicited Human Sera. Science 2021, 371, 1152-1153. [CrossRef]

71. Gallais, F.; Gantner, P.; Bruel, T.; Velay, A.; Planas, D.; Wendling, M.-J.; Bayer, S.; Solis, M.; Laugel, E.; Reix, N.; et al. Anti-SARSCoV-2 Antibodies Persist for up to 13 Months and Reduce Risk of Reinfection. medRxiv 2021. [CrossRef] 
72. Graham, M.S.; Sudre, C.H.; May, A.; Antonelli, M.; Murray, B.; Varsavsky, T.; Kläser, K.; Canas, L.S.; Molteni, E.; Modat, M.; et al. Changes in Symptomatology, Reinfection, and Transmissibility Associated with the SARS-CoV-2 Variant B.1.1.7: An Ecological Study. Lancet Public Health 2021, 6, e335-e345. [CrossRef]

73. Meyer, E.D.; Sandfort, M.; Bender, J.; Matysiak-Klose, D.; Dörre, A.; Bojara, G.; Beyrer, K.; Hellenbrand, W. Two Doses of the MRNA BNT162b2 Vaccine Reduce Severe Outcomes, Viral Load and Secondary Attack Rate: Evidence from a SARS-CoV-2 Alpha Outbreak in a Nursing Home in Germany, January-March 2021. medRxiv 2021. [CrossRef]

74. Glatman-Freedman, A.; Bromberg, M.; Dichtiar, R.; Hershkovitz, Y.; Keinan-Boker, L. The BNT162b2 Vaccine Effectiveness against New COVID-19 Cases and Complications of Breakthrough Cases: A Nation-Wide Retrospective Longitudinal Multiple Cohort Analysis Using Individualised Data. EBioMedicine 2021, 72, 103574. [CrossRef] [PubMed]

75. Hagan, L.M.; McCormick, D.W.; Lee, C.; Sleweon, S.; Nicolae, L.; Dixon, T.; Banta, R.; Ogle, I.; Young, C.; Dusseau, C.; et al. Outbreak of SARS-CoV-2 B.1.617.2 (Delta) Variant Infections Among Incarcerated Persons in a Federal Prison-Texas, July-August 2021. MMWR. Morb. Mortal. Wkly. Rep. 2021, 70, 1349-1354. [CrossRef]

76. Emary, K.R.W.; Golubchik, T.; Aley, P.K.; Ariani, C.V.; Angus, B.; Bibi, S.; Blane, B.; Bonsall, D.; Cicconi, P.; Charlton, S.; et al. Efficacy of ChAdOx1 NCoV-19 (AZD1222) Vaccine against SARS-CoV-2 Variant of Concern 202012/01 (B.1.1.7): An Exploratory Analysis of a Randomised Controlled Trial. Lancet 2021, 397, 1351-1362. [CrossRef]

77. Shinde, V.; Bhikha, S.; Hoosain, Z.; Archary, M.; Bhorat, Q.; Fairlie, L.; Lalloo, U.; Masilela, M.S.L.; Moodley, D.; Hanley, S.; et al. Efficacy of NVX-CoV2373 Covid-19 Vaccine against the B.1.351 Variant. N. Engl. J. Med. 2021, 384, 1899-1909. [CrossRef]

78. Madhi, S.A.; Baillie, V.; Cutland, C.L.; Voysey, M.; Koen, A.L.; Fairlie, L.; Padayachee, S.D.; Dheda, K.; Barnabas, S.L.; Bhorat, Q.E.; et al. Efficacy of the ChAdOx1 NCoV-19 Covid-19 Vaccine against the B.1.351 Variant. N. Engl. J. Med. 2021, 384, 1885-1898. [CrossRef]

79. Sadoff, J.; Gray, G.; Vandebosch, A.; Cárdenas, V.; Shukarev, G.; Grinsztejn, B.; Goepfert, P.A.; Truyers, C.; Fennema, H.; Spiessens, B.; et al. Safety and Efficacy of Single-Dose Ad26.COV2.S Vaccine against Covid-19. N. Engl. J. Med. 2021, 384, 2187-2201. [CrossRef]

80. Shinde, V.; Bhikha, S.; Hossain, Z.; Archary, M.; Bhorat, Q. Preliminary Efficacy of the NVX-CoV2373 Covid-19 Vaccine against the b. 1.351 Variant. medRxiv 2021. [CrossRef]

81. Thomas, S.J.; Moreira, E.D.; Kitchin, N.; Absalon, J.; Gurtman, A.; Lockhart, S.; Perez, J.L.; Pérez Marc, G.; Polack, F.P.; Zerbini, C.; et al. Six Month Safety and Efficacy of the BNT162b2 MRNA COVID-19 Vaccine. medRxiv 2021. [CrossRef]

82. Ella, R.; Reddy, S.; Blackwelder, W.; Potdar, V.; Yadav, P.; Sarangi, V.; Aileni, V.K.; Kanungo, S.; Rai, S.; Reddy, P.; et al. Efficacy, Safety, and Lot to Lot Immunogenicity of an Inactivated SARS-CoV-2 Vaccine (BBV152): A, Double-Blind, Randomised, Controlled Phase 3 Trial. medRxiv 2021. [CrossRef]

83. SARS-CoV-2 Viral Mutations: Impact on COVID-19 Tests. Available online: https://www.fda.gov/medical-devices/ coronavirus-covid-19-and-medical-devices/sars-cov-2-viral-mutations-impact-covid-19-tests\#: :text=The \% 20presence\%20 of $\% 20$ mutations $\% 20$ in, the $\% 20$ variant $\% 20 \mathrm{in} \% 20$ the $\% 20$ population (accessed on 2 August 2021).

84. SARS-CoV-2 Variant-United Kingdom of Great Britain and Northern Ireland. Available online: https://www.who.int/csr/don/ 21-december-2020-sars-cov2-variant-united-kingdom/en/ (accessed on 2 August 2021).

85. Virus Variants are Expected, But Surveillance Should Continue to Monitor Possible Changes in Clinical Patterns, Experts Say. Available online: https:/ / www.paho.org/en/news/14-5-2021-virus-variants-are-expected-surveillance-should-continuemonitor-possible-changes (accessed on 2 August 2021).

86. Coronavirus Disease (COVID-19): Serology, Antibodies and Immunity. Available online: https://www.who.int/news-room/q-adetail/coronavirus-disease-covid-19-serology (accessed on 10 August 2021).

87. Center for Disease Control and Prevention Interim Guidelines for COVID-19 Antibody Testing. Interim Guidelines for COVID-19 Antibody Testing in Clinical and Public Health Settings. Update 17 March 2021. Available online: https://www.cdc.gov/ coronavirus/2019-ncov/lab/resources/antibody-tests-guidelines.html (accessed on 9 July 2021).

88. Winter, A.K.; Hegde, S.T. The Important Role of Serology for COVID-19 Control. Lancet Infect. Dis. 2020, 20, 758-759. [CrossRef]

89. Muruato, A.E.; Fontes-Garfias, C.R.; Ren, P.; Garcia-Blanco, M.A.; Menachery, V.D.; Xie, X.; Shi, P.Y. A High-Throughput Neutralizing Antibody Assay for COVID-19 Diagnosis and Vaccine Evaluation. Nat. Commun. 2020, 11, 4059. [CrossRef] [PubMed]

90. Lisboa Bastos, M.; Tavaziva, G.; Abidi, S.K.; Campbell, J.R.; Haraoui, L.P.; Johnston, J.C.; Lan, Z.; Law, S.; MacLean, E.; Trajman, A.; et al. Diagnostic Accuracy of Serological Tests for Covid-19: Systematic Review and Meta-Analysis. BMJ 2020, 370, m2516. [CrossRef]

91. Kontou, P.I.; Braliou, G.G.; Dimou, N.L.; Nikolopoulos, G.; Bagos, P.G. Antibody Tests in Detecting SARS-CoV-2 Infection: A Meta-Analysis. Diagnostics 2020, 10, 319. [CrossRef] [PubMed]

92. Sethuraman, N.; Jeremiah, S.S.; Ryo, A. Interpreting Diagnostic Tests for SARS-CoV-2. JAMA 2020, 323, 2249. [CrossRef] [PubMed]

93. Yu, H.Q.; Sun, B.Q.; Fang, Z.F.; Zhao, J.C.; Liu, X.Y.; Li, Y.M.; Sun, X.Z.; Liang, H.F.; Zhong, B.; Huang, Z.F.; et al. Distinct Features of SARS-CoV-2-Specific IgA Response in COVID-19 Patients. Eur. Respir. J. 2020, 56, 2001526. [CrossRef]

94. Qu, J.; Wu, C.; Li, X.; Zhang, G.; Jiang, Z.; Li, X.; Zhu, Q.; Liu, L. Profile of Immunoglobulin G and IgM Antibodies against Severe Acute Respiratory Syndrome Coronavirus 2 (SARS-CoV-2). Clin. Infect. Dis. 2020, 71, 2255-2258. [CrossRef] [PubMed] 
95. Iyer, A.S.; Jones, F.K.; Nodoushani, A.; Kelly, M.; Becker, M.; Slater, D.; Mills, R.; Teng, E.; Kamruzzaman, M.; Garcia-Beltran, W.F.; et al. Persistence and Decay of Human Antibody Responses to the Receptor Binding Domain of SARS-CoV-2 Spike Protein in COVID-19 Patients. Sci. Immunol. 2020, 5, eabe0367. [CrossRef]

96. Ghaffari, A.; Meurant, R.; Ardakani, A. COVID-19 Serological Tests: How Well Do They Actually Perform? Diagnostics 2020, 10, 453. [CrossRef] [PubMed]

97. McAndrews, K.M.; Dowlatshahi, D.P.; Dai, J.; Becker, L.M.; Hensel, J.; Snowden, L.M.; Leveille, J.M.; Brunner, M.R.; Holden, K.W.; Hopkins, N.S.; et al. Heterogeneous Antibodies against SARS-CoV-2 Spike Receptor Binding Domain and Nucleocapsid with Implications for COVID-19 Immunity. JCI Insight 2020, 5, e142386. [CrossRef]

98. Grifoni, A.; Weiskopf, D.; Ramirez, S.I.; Mateus, J.; Dan, J.M.; Moderbacher, C.R.; Rawlings, S.A.; Sutherland, A.; Premkumar, L.; Jadi, R.S.; et al. Targets of T Cell Responses to SARS-CoV-2 Coronavirus in Humans with COVID-19 Disease and Unexposed Individuals. Cell 2020, 181, 1489-1501. [CrossRef]

99. Robbiani, D.F.; Gaebler, C.; Muecksch, F.; Lorenzi, J.C.C.; Wang, Z.; Cho, A.; Agudelo, M.; Barnes, C.O.; Gazumyan, A.; Finkin, S.; et al. Convergent Antibody Responses to SARS-CoV-2 in Convalescent Individuals. Nature 2020, 584, 437-442. [CrossRef]

100. Suthar, M.S.; Zimmerman, M.G.; Kauffman, R.C.; Mantus, G.; Linderman, S.L.; Hudson, W.H.; Vanderheiden, A.; Nyhoff, L.; Davis, C.W.; Adekunle, O.; et al. Rapid Generation of Neutralizing Antibody Responses in COVID-19 Patients. Cell Rep. Med. 2020, 1, 100040. [CrossRef]

101. Carrillo, J.; Izquierdo-Useros, N.; Ávila-Nieto, C.; Pradenas, E.; Clotet, B.; Blanco, J. Humoral Immune Responses and Neutralizing Antibodies against SARS-CoV-2; Implications in Pathogenesis and Protective Immunity. Biochem. Biophys. Res. Commun. 2021, 538, 187-191. [CrossRef] [PubMed]

102. Tai, W.; He, L.; Zhang, X.; Pu, J.; Voronin, D.; Jiang, S.; Zhou, Y.; Du, L. Characterization of the Receptor-Binding Domain (RBD) of 2019 Novel Coronavirus: Implication for Development of RBD Protein as a Viral Attachment Inhibitor and Vaccine. Cell. Mol. Immunol. 2020, 17, 613-620. [CrossRef] [PubMed]

103. Tay, M.Z.; Poh, C.M.; Rénia, L.; MacAry, P.A.; Ng, L.F.P. The Trinity of COVID-19: Immunity, Inflammation and Intervention. Nat. Rev. Immunol. 2020, 20, 363-374. [CrossRef]

104. Mazzini, L.; Martinuzzi, D.; Hyseni, I.; Benincasa, L.; Molesti, E.; Casa, E.; Lapini, G.; Piu, P.; Trombetta, C.M.; Marchi, S.; et al. Comparative Analyses of SARS-CoV-2 Binding (IgG, IgM, IgA) and Neutralizing Antibodies from Human Serum Samples. J. Immunol. Methods 2021, 489, 112937. [CrossRef]

105. Wölfel, R.; Corman, V.M.; Guggemos, W.; Seilmaier, M.; Zange, S.; Müller, M.A.; Niemeyer, D.; Jones, T.C.; Vollmar, P.; Rothe, C.; et al. Virological Assessment of Hospitalized Patients with COVID-2019. Nature 2020, 581, 465-469. [CrossRef] [PubMed]

106. Dan, J.M.; Mateus, J.; Kato, Y.; Hastie, K.M.; Faliti, C.E.; Ramirez, S.I.; Frazier, A.; Dawen Yu, E.; Grifoni, A.; Rawlings, S.A.; et al. Immunological Memory to SARS-CoV-2 Assessed for Greater than Eight Months after Infection. Science 2020, 371 , eabf4063. [CrossRef]

107. Schultz, A.; Koch, S.; Fuss, M.; Mazzotta, A.S.; Sarzotti-Kelsoe, M.; Ozaki, D.A.; Montefiori, D.C.; von Briesen, H.; Zimmermann, H.; Meyerhans, A. An Automated HIV-1 Env-Pseudotyped Virus Production for Global HIV Vaccine Trials. PLoS ONE 2012, 7, e51715. [CrossRef]

108. Donofrio, G.; Franceschi, V.; Macchi, F.; Russo, L.; Rocci, A.; Marchica, V.; Costa, F.; Giuliani, N.; Ferrari, C.; Missale, G. A Simplified Sars-Cov-2 Pseudovirus Neutralization Assay. Vaccines 2021, 9, 389. [CrossRef]

109. Prendecki, M.; Clarke, C.; Edwards, H.; McIntyre, S.; Mortimer, P.; Gleeson, S.; Martin, P.; Thomson, T.; Randell, P.; Shah, A.; et al. Humoral and T-Cell Responses to SARS-CoV-2 Vaccination in Patients Receiving Immunosuppression. Ann. Rheum. Dis. 2021, 80, 1322-1329. [CrossRef]

110. Timeline: Tracking Latin America's Road to Vaccination. Americas Society Council of the Americas Archived. Available online: https: / / www.as-coa.org/articles/timeline-tracking-latin-americas-road-vaccination (accessed on 4 May 2021).

111. COVAX Explained. 3 September-By Dr Seth Berkley, CEO of Gavi, the Vaccine Alliance. Available online: https://www.gavi. org/vaccineswork/covax-explained (accessed on 24 September 2021).

112. Countries in the Americas Notified of First COVID-19 Vaccine Allocations Through COVAX. Available online: https:// www.paho.org/en/news/31-1-2021-countries-americas-notified-first-covid-19-vaccine-allocations-through-covax (accessed on 24 September 2021).

113. COVAX and the United States. Available online: https://www.kff.org/coronavirus-covid-19/issue-brief/covax-and-the-unitedstates / (accessed on 24 September 2021).

114. What is COVAX and What Does it Mean for Latin America? Americas Society Council of the Americas Archived. Available online: https: / / www.as-coa.org/articles/what-covax-and-what-does-it-mean-latin-america\#covax-in-latin-america-and-thecaribbean (accessed on 7 June 2021).

115. Gavi Launches Innovative Financing Mechanism for Access to COVID-19 Vaccines. Available online: https:/ /www.gavi.org/ news/media-room/gavi-launches-innovative-financing-mechanism-access-covid-19-vaccines (accessed on 7 June 2021).

116. COVID-19 Vaccination Moves Slowly in Latin America. Despite Several Agreements, Vaccination Rate Remains Low in Countries as Large Number of Doses yet to be Received. Available online: https:/ / www.aa.com.tr/en/americas/covid-19-vaccinationmoves-slowly-in-latin-america/2188034 (accessed on 7 June 2021).

117. Our World in Data: COVID-19 Vaccination Policy. Available online: https:/ / ourworldindata.org/grapher/covid-vaccinationpolicy (accessed on 26 September 2021). 
118. Ministry of Health of Argentina. Plan Estratégico Para la Vacunación Contra la COVID-19 en Argentina; Ministry of Health of Argentina: Buenos Aires, Argentina, 2020; pp. 1-28. Available online: https://www.argentina.gob.ar/sites/default/files/ coronavirus-vacuna-plan-estrategico-vacunacion-covid-19-diciembre-2020.pdf (accessed on 7 June 2021).

119. Ministry of Health of Brazil. Plano Nacional de Operacionalização da Vacinação Contra a COVID-19, 5th ed.; Ministry of Health of Brazil: Brasília, Brazil, 2021. Available online: https://www.gov.br/saude/pt-br/coronavirus/publicacoes-tecnicas/guias-eplanos/plano-nacional-de-vacinacao-covid-19/view (accessed on 7 June 2021).

120. Government of Chile. Plan Nacional de Vacunación COVID-19. Available online: https://www.gob.cl/yomevacuno/ (accessed on 7 June 2021).

121. Government of Colombia. Plan de Vacunación Contra el COVID 19; Government of Colombia: Bogotá, Colombia, 2021; pp. 1-95. Available online: https://www.minsalud.gov.co/sites/rid/Lists/BibliotecaDigital/RIDE/VS/pnv-contra-covid19.pdf (accessed on 7 June 2021).

122. Ministry of Health of Colombia. La Prioridad Para la Vacunación Serán los Grupos de Riesgo. Available online: https: //www.minsalud.gov.co/Paginas/La-prioridad-para-la-vacunacion-seran-los-grupos-de-riesgo.aspx (accessed on 7 June 2021).

123. Government of Mexico. Política Nacional Rectora de Vacunación Contra el Virus SARS-Cov-2 Para La Prevención de la COVID-19; Government of Mexico: Mexico City, Mexico, 2021; pp. 1-39. Available online: https://coronavirus.gob.mx/wp-content/ uploads/2021/01/PolVx_COVID_-11Ene2021.pdf (accessed on 7 June 2021).

124. Pan-American Health Organization. Regulatory System Strengthening in the Americas. Lessons Learned from the National Regulatory Authorities of Regional Reference; PAHO: Washington, DC, USA, 2021; pp. 1-134. Available online: https://iris.paho.org/handle/ 10665.2/53793 (accessed on 7 June 2021).

125. PAHO Warns Against Getting COVID-19 Vaccines Outside of Official Channels. Available online: https://www.paho.org/en/ news/22-4-2021-paho-warns-against-getting-covid-19-vaccines-outside-official-channels (accessed on 11 July 2021).

126. Cronología: Rastreando el Camino Hacia la Vacunación en América Latina. Americas Society Council of the Americas Archived. Available online: https:/ / www.as-coa.org/articles/cronologia-rastreando-el-camino-hacia-la-vacunacion-en-america-latina (accessed on 11 July 2021).

127. Argentina Recibiría Menos Vacunas de las Esperadas por el Mecanismo COVAX. Available online: https://www.aa.com. $\mathrm{tr} / \mathrm{es} / \mathrm{mundo} /$ argentina-recibir\%C3\%ADa-menos-vacunas-de-las-esperadas-por-el-mecanismo-covax/2133177 (accessed on 11 July 2021).

128. Vaccine Rollout in Latin America: Which Countries are Setting the Pace? Available online: https://oxfordbusinessgroup.com/ news/vaccine-rollout-latin-america-which-countries-are-setting-pace (accessed on 11 July 2021).

129. Vacunar Primero en Zonas Remotas es Mala Idea. Available online: https://politica.expansion.mx/voces/2021/01/06/vacunarprimero-en-zonas-remotas-es-mala-idea (accessed on 11 July 2021).

130. Our World In Data. Statistics and Research: Coronavirus (COVID-19) Vaccinations. Available online: https: / ourworldindata. org/covid-vaccinations (accessed on 28 October 2021).

131. Cutts, F.T.; Hanson, M. Seroepidemiology: An Underused Tool for Designing and Monitoring Vaccination Programmes in Lowand Middle-Income Countries. Trop. Med. Int. Health 2016, 21, 1086-1098. [CrossRef] [PubMed]

132. World Health Organization Regional Office for Europe. Guidance on Conducting Serosurveys in Support of Measles and Rubella Elimination in the WHO European Region; World Health Organization Regional Office for Europe: Copenhagen, Denmark, 2013; pp. 1-25. Available online: https:/ /www.euro.who.int/_data/assets/pdf_file/0011/236648/Guidance-on-conductingserosurveys-in-support-of-measles-and-rubella-elimination-in-the-WHO-European-Region.pdf (accessed on 4 May 2020).

133. Saaka, M.; Okoko, B.J.; Kohberger, R.C.; Jaffar, S.; Enwere, G.; Biney, E.E.; Oluwalana, C.; Vaughan, A.; Zaman, S.M.A.; Asthon, L.; et al. Immunogenicity and Serotype-Specific Efficacy of a 9-Valent Pneumococcal Conjugate Vaccine (PCV-9) Determined during an Efficacy Trial in The Gambia. Vaccine 2008, 26, 3719-3726. [CrossRef]

134. Pinto, L.A.; Dillner, J.; Beddows, S.; Unger, E.R. Immunogenicity of HPV Prophylactic Vaccines: Serology Assays and Their Use in HPV Vaccine Evaluation and Development. Vaccine 2018, 36, 4792-4799. [CrossRef] [PubMed]

135. World Health Organization. Immunity Passports in the Context of COVID-19: Scientific Brief; Contract No.: WHO/2019nCoV/Sci_Brief/Immunity_passport/2020.1; World Health Organization: Geneva, Switzerland, 2020; pp. 1-2. Available online: https: / /apps.who.int/iris/bitstream/handle/10665/331866/WHO-2019-nCoV-Sci_Brief-Immunity_passport-2020.1 -eng.pdf (accessed on 5 May 2021).

136. World Health Organization. COVID-19 Diagnostic Testing in the Context of International Travel. Scientific Brief; WHO/2019nCoV/Sci_Brief/international_travel_testing/2020; World Health Organization: Geneva, Switzerland, 2020; pp. 1-4. Available online: https://www.who.int/publications/i/item/WHO-2019-nCoV-Sci_Brief-international_travel_testing-2020.1\#.X9zOFuP5 Pl0.linkedin (accessed on 5 May 2021).

137. World Health Organization. Protocolo Para Estudios Seroepidemiológicos Poblacionales Sobre la COVID-19, con Estratificación por Edades; WHO/2019-nCoV/Seroepidemiology/2020.1; World Health Organization: Geneva, Switzerland, 2020; pp. 1-18. Available online: https:/ /apps.who.int/iris/handle/10665/331540 (accessed on 5 May 2021).

138. Pan-American Health Organization. Directrices de Laboratorio para la Detección y el Diagnóstico de la Infección por el Virus Responsable de la COVID-19, 8 de Julio del 2020; Pan-American Health Organization: New York, NY, USA, 2021; pp. 1-11. Available online: https:/ / www.paho.org/es/documentos/directrices-laboratorio-para-deteccion-diagnostico-infeccion-con-virus-covid-19 (accessed on 5 May 2021). 
139. Kresin, C.; Schoenberg, F.; Mohler, G. Comparison of Hawkes and SEIR Models for the Spread of COVID-19. Statistical Science 2020. Available online: http://www.stat.ucla.edu/ frederic/papers/conor8.pdf (accessed on 31 October 2021).

140. Sood, N.; Simon, P.; Ebner, P.; Eichner, D.; Reynolds, J.; Bendavid, E.; Bhattacharya, J. Seroprevalence of SARS-CoV-2-Specific Antibodies among Adults in Los Angeles County, California, on April 10-11, 2020. JAMA 2020, 323, 2425-2427. [CrossRef]

141. Bendavid, E.; Mulaney, B.; Sood, N.; Shah, S.; Bromley-Dulfano, R.; Lai, C.; Weissberg, Z.; Saavedra-Walker, R.; Tedrow, J.; Bogan, A.; et al. COVID-19 Antibody Seroprevalence in Santa Clara County, California. Int. J. Epidemiol. 2021, 50, 410-419. [CrossRef] [PubMed]

142. Day, M. Covid-19: Identifying and Isolating Asymptomatic People Helped Eliminate Virus in Italian Village. BMJ 2020, 368, m1165. [CrossRef] [PubMed]

143. Bertozzi, A.L.; Franco, E.; Mohler, G.; Short, M.B.; Sledge, D. The Challenges of Modeling and Forecasting the Spread of COVID-19. Proc. Natl. Acad. Sci. USA 2020, 117, 16732-16738. [CrossRef]

144. Most of the World's Population is Still Susceptible to COVID-19, Even if they Have Already Had It. Available online: https: / / coronavirus.onu.org.mx/la-mayor-parte-de-la-poblacion-mundial-sigue-siendo-susceptible-a-la-covid-19-aunqueya-la-haya-padecido (accessed on 5 May 2021).

145. FDA Statement: Coronavirus (COVID-19) Update: Serological Tests, 7 April 2021. Available online: https://www.fda.gov/newsevents/press-announcements / coronavirus-covid-19-update-serological-tests (accessed on 5 May 2021).

146. Antibody Testing Is Not Currently Recommended to Assess Immunity after COVID-19 Vaccination: FDA Safety Communication, 19 May 2021. Available online: https:/ / www.fda.gov/medical-devices/safety-communications/antibody-testing-not-currentlyrecommended-assess-immunity-after-covid-19-vaccination-fda-safety (accessed on 27 May 2021).

147. Ministry of Health of Argentina. Consensus on the Use of Diagnostic Tests for SARS-Cov-2, 2nd Version; Ministry of Health of Argentina: Buenos Aires, Argentina, 2021; pp. 1-36. Available online: https://www.fundacionfemeba.org.ar/blog/farmacologia7 / post/consenso-sobre-el-uso-de-pruebas-diagnosticas-para-sars-cov-2-version-2-49075 (accessed on 27 May 2021).

148. El Test Serológico Argentino para COVID-19 Llegó a los 100.000 Ensayos. Available online: https:/ / www.argentina.gob.ar/ noticias / el-test-serologico-argentino-para-covid-19-1lego-los-100000-ensayos (accessed on 27 May 2021).

149. Government of the State of Minas Gerais. Manual Do Diagnóstico Coordenação Estadual De Laboratórios E Pesquisa Em Vigilância; Versão 1; Government of the State of Minas Gerais: Minas Gerais, Brazil, 2020; pp. 1-44. Available online: https://coronavirus. saude.mg.gov.br/images/profissionais-e-gestores/27-08_Manual_Diagnostico_Covid-19.pdf (accessed on 27 May 2021).

150. Sociedad Científica de Médicos Especialistas en Laboratorio Clínico de Chile. Recomendaciones para la Prueba de Anticuerpos Contra SARS-Cov 2 (COVID-19); Versión 1.0_02/07/2020; Sociedad Científica de Médicos Especialistas en Laboratorio Clínico de Chile: Santiago de Chile, Chile, 2020; pp. 1-10. Available online: http://www.smlc.cl/wp-content/uploads/2020/07/ Recomendaciones-para-la-prueba-de-anticuerpos-SMLC_final.pdf (accessed on 27 May 2021).

151. Pruebas Serológicas: ¿Qué Son y Para Qué Sirven Ante el COVID-19? Available online: https://tec.mx/es/noticias/nacional/ salud/pruebas-serologicas-que-son-y-para-que-sirven-ante-el-covid-19 (accessed on 27 May 2021).

152. SeroTracker. Available online: https:/ / serotracker.com/en/Explore (accessed on 28 October 2021).

153. Sauré, D.; O’Ryan, M.; Torres, J.P.; Zuniga, M.; Santelices, E.; Basso, L.J. Dynamic IgG Seropositivity after Rollout of CoronaVac and BNT162b2 COVID-19 Vaccines in Chile: A Sentinel Surveillance Study. Lancet Infect. Dis. 2021. [CrossRef]

154. Sobre el Uso de Tests de Detección de Anticuerpos para COVID-19. Available online: https://www.argentina.gob.ar/noticias/ sobre-el-uso-de-tests-de-deteccion-de-anticuerpos-para-covid-19 (accessed on 27 May 2021).

155. Saavedra Trujillo, C.H. Resumen: Consenso Colombiano de Atención, Diagnóstico y Manejo de La Infección Por SARS-COV2/COVID-19 En Establecimientos de Atención de La Salud-Recomendaciones Basadas En Consenso de Expertos e Informadas En La Evidencia. Infectio 2020, 24, 186-261. [CrossRef]

156. Advice On the Use of Point-Of-Care Immunodiagnostic Tests for COVID-19. Technical Brief 8 April 2020. Available online: https:/ / www.who.int/news-room/commentaries/detail/advice-on-the-use-of-point-of-care-immunodiagnostic-testsfor-covid-19 (accessed on 27 May 2021).

157. Burgess, S.; Ponsford, M.J.; Gill, D. Are We Underestimating Seroprevalence of SARS-CoV-2? BMJ 2020, 370, m3364. [CrossRef]

158. Ministry of Health of Brazil. Acurácia Dos Testes Diagnósticos Registrados Na ANVISA Para A COVID-19; Ministry of Health of Brazil: Brasilia, Brazil, 2020; pp. 1-35. Available online: https://portalarquivos2.saude.gov.br/images/pdf/2020/June/02 / AcuraciaDiagnostico-COVID19-atualizacaoC.pdf (accessed on 27 May 2021).

159. Hicks, J.; Klumpp-Thomas, C.; Kalish, H.; Shunmugavel, A.; Mehalko, J.; Denson, J.P.; Snead, K.R.; Drew, M.; Corbett, K.S.; Graham, B.S.; et al. Serologic Cross-Reactivity of SARS-CoV-2 with Endemic and Seasonal Betacoronaviruses. J. Clin. Immunol. 2021, 41, 1-8. [CrossRef]

160. Klumpp-Thomas, C.; Kalish, H.; Hicks, J.; Mehalko, J.; Drew, M.; Memoli, M.J.; Hall, M.D.; Esposito, D.; Sadtler, K. Effect of D614G Spike Variant on Immunoglobulin G, M, or A Spike Seroassay Performance. J. Infect. Dis. 2021, 223, 802-804. [CrossRef]

161. Klumpp-Thomas, C.; Kalish, H.; Drew, M.; Hunsberger, S.; Snead, K.; Fay, M.P.; Mehalko, J.; Shunmugavel, A.; Wall, V.; Frank, P.; et al. Standardization of ELISA Protocols for Serosurveys of the SARS-CoV-2 Pandemic Using Clinical and at-Home Blood Sampling. Nat. Commun. 2021, 12, 1-13. [CrossRef]

162. Piec, I.; English, E.; Thomas, M.A.; Dervisevic, S.; Fraser, W.D.; John, W.G. Performance of SARS-CoV-2 Serology Tests: Are They Good Enough? PLoS ONE 2021, 16, e0245914. [CrossRef] [PubMed] 
163. Kalish, H.; Klumpp-Thomas, C.; Hunsberger, S.; Baus, H.A.; Fay, M.P.; Siripong, N.; Wang, J.; Hicks, J.; Mehalko, J.; Travers, J.; et al. Undiagnosed SARS-CoV-2 Seropositivity during the First 6 Months of the COVID-19 Pandemic in the United States. Sci. Transl. Med. 2021, 13, eabh3826. [CrossRef]

164. Petersen, L.R.; Sami, S.; Vuong, N.; Pathela, P.; Weiss, D.; Morgenthau, B.M.; Henseler, R.A.; Daskalakis, D.C.; Atas, J.; Patel, A.; et al. Lack of Antibodies to SARS-CoV-2 in a Large Cohort of Previously Infected Persons. Clin. Infect. Dis. 2020, 73, e3066-e3073. [CrossRef]

165. Kaufman, H.W.; Chen, Z.; Meyer, W.A.; Wohlgemuth, J.G. Insights from Patterns of SARS-CoV-2 Immunoglobulin G Serology Test Results from a National Clinical Laboratory, United States, March-July 2020. Popul. Health Manag. 2021, 24, S-35-S-42. [CrossRef]

166. Choe, P.G.; Kang, C.K.; Suh, H.J.; Jung, J.; Kang, E.K.; Lee, S.Y.; Song, K.H.; Kim, H.B.; Kim, N.J.; Park, W.B.; et al. Antibody Responses to SARS-CoV-2 at 8 Weeks Postinfection in Asymptomatic Patients. Emerg. Infect. Dis. 2020, 26, 2484-2487. [CrossRef]

167. Hall, V.J.; Foulkes, S.; Charlett, A.; Atti, A.; Monk, E.J.M.; Simmons, R.; Wellington, E.; Cole, M.J.; Saei, A.; Oguti, B.; et al. SARS-CoV-2 Infection Rates of Antibody-Positive Compared with Antibody-Negative Health-Care Workers in England: A Large, Multicentre, Prospective Cohort Study (SIREN). Lancet 2021, 397, 1459-1469. [CrossRef]

168. Hansen, C.H.; Michlmayr, D.; Gubbels, S.M.; Mølbak, K.; Ethelberg, S. Assessment of Protection against Reinfection with SARS-CoV-2 among 4 Million PCR-Tested Individuals in Denmark in 2020: A Population-Level Observational Study. Lancet 2021, 397, 1204-1212. [CrossRef]

169. Pilz, S.; Chakeri, A.; Ioannidis, J.P.A.; Richter, L.; Theiler-Schwetz, V.; Trummer, C.; Krause, R.; Allerberger, F. SARS-CoV-2 Re-Infection Risk in Austria. Eur. J. Clin. Investig. 2021, 51, e13520. [CrossRef]

170. Lumley, S.F.; O’Donnell, D.; Stoesser, N.E.; Matthews, P.C.; Howarth, A.; Hatch, S.B.; Marsden, B.D.; Cox, S.; James, T.; Warren, F.; et al. Antibody Status and Incidence of SARS-CoV-2 Infection in Health Care Workers. N. Engl. J. Med. 2021, 384, 533-540. [CrossRef]

171. Plotkin, S.A.; Gilbert, P.B. Nomenclature for Immune Correlates of Protection after Vaccination. Clin. Infect. Dis. 2012, 54, 1615-1617. [CrossRef]

172. Qin, L.; Gilbert, P.B.; Corey, L.; McElrath, M.J.; Self, S.G. A Framework for Assessing Immunological Correlates of Protection in Vaccine Trials. J. Infect. Dis. 2007, 196, 1304-1312. [CrossRef]

173. Milani, G.P.; Dioni, L.; Favero, C.; Cantone, L.; Macchi, C.; Delbue, S.; Bonzini, M.; Montomoli, E.; Bollati, V.; Albetti, B.; et al. Serological Follow-up of SARS-CoV-2 Asymptomatic Subjects. Sci. Rep. 2020, 10, 1-7. [CrossRef]

174. Rijkers, G.; Murk, J.L.; Wintermans, B.; van Looy, B.; van den Berge, M.; Veenemans, J.; Stohr, J.; Reusken, C.; van der Pol, P.; Reimerink, J. Differences in Antibody Kinetics and Functionality between Severe and Mild Severe Acute Respiratory Syndrome Coronavirus 2 Infections. J. Infect. Dis. 2020, 222, 1265-1269. [CrossRef]

175. Letizia, A.G.; Ge, Y.; Vangeti, S.; Goforth, C.; Weir, D.L.; Kuzmina, N.A.; Balinsky, C.A.; Chen, H.W.; Ewing, D.; Soares-Schanoski, A.; et al. SARS-CoV-2 Seropositivity and Subsequent Infection Risk in Healthy Young Adults: A Prospective Cohort Study. Lancet Respir. Med. 2021, 9, 712-720. [CrossRef]

176. Selhorst, P.; van Ierssel, S.H.; Michiels, J.; Mariën, J.; Bartholomeeusen, K.; Dirinck, E.; Vandamme, S.; Jansens, H.; Ariën, K.K. Symptomatic Severe Acute Respiratory Syndrome Coronavirus 2 Reinfection of a Healthcare Worker in a Belgian Nosocomial Outbreak Despite Primary Neutralizing Antibody Response. Clin. Infect. Dis. 2020, 73, e2985-e2991. [CrossRef]

177. To, K.K.W.; Tsang, O.T.Y.; Leung, W.S.; Tam, A.R.; Wu, T.C.; Lung, D.C.; Yip, C.C.Y.; Cai, J.P.; Chan, J.M.C.; Chik, T.S.H.; et al. Temporal Profiles of Viral Load in Posterior Oropharyngeal Saliva Samples and Serum Antibody Responses during Infection by SARS-CoV-2: An Observational Cohort Study. Lancet Infect. Dis. 2020, 20, 565-574. [CrossRef]

178. Addetia, A.; Crawford, K.H.D.; Dingens, A.; Zhu, H.; Roychoudhury, P.; Huang, M.L.; Jerome, K.R.; Bloom, J.D.; Greninger, A.L. Neutralizing Antibodies Correlate with Protection from SARS-CoV-2 in Humans during a Fishery Vessel Outbreak with a High Attack Rate. J. Clin. Microbiol. 2020, 58, e02107-20. [CrossRef]

179. Pray, I.W.; Gibbons-Burgener, S.N.; Rosenberg, A.Z.; Cole, D.; Borenstein, S.; Bateman, A.; Pevzner, E.; Westergaard, R.P. COVID19 Outbreak at an Overnight Summer School Retreat-Wisconsin, July-August 2020. MMWR. Morb. Mortal. Wkly. Rep. 2020, 69, 1600-1604. [CrossRef]

180. Jeffery-Smith, A.; Iyanger, N.; Williams, S.V.; Chow, J.Y.; Aiano, F.; Hoschler, K.; Lackenby, A.; Ellis, J.; Platt, S.; Miah, S.; et al. Antibodies to SARS-CoV-2 Protect against Re-Infection during Outbreaks in Care Homes, September and October 2020. Eurosurveillance 2021, 26, 2100092. [CrossRef]

181. Harvey, R.A.; Rassen, J.A.; Kabelac, C.A.; Turenne, W.; Leonard, S.; Klesh, R.; Meyer, W.A.; Kaufman, H.W.; Anderson, S.; Cohen, O.; et al. Real-World Data Suggest Antibody Positivity to SARS-CoV-2 Is Associated with a Decreased Risk of Future Infection. medRxiv 2020. [CrossRef]

182. Letizia, A.G.; Ge, Y.; Goforth, C.W.; Weir, D.L.; Lizewski, R.; Lizewski, S.; Soares-Schanoski, A.; Vangeti, S.; Marjanovic, N.; Sealfon, S.C.; et al. SARS-CoV-2 Seropositivity among US Marine Recruits Attending Basic Training, United States, Spring-Fall 2020. Emerg. Infect. Dis. 2021, 27, 1188-1192. [CrossRef]

183. Feng, S.; Phillips, D.J.; White, T.; Sayal, H.; Aley, P.K.; Bibi, S.; Dold, C.; Fuskova, M.; Gilbert, S.C.; Hirsch, I.; et al. Correlates of Protection against Symptomatic and Asymptomatic SARS-CoV-2 Infection. Nat. Med. 2021, 27, 2032-2040. [CrossRef] [PubMed]

184. Voysey, M.; Clemens, S.A.C.; Madhi, S.A.; Weckx, L.Y.; Folegatti, P.M.; Aley, P.K.; Angus, B.; Baillie, V.L.; Barnabas, S.L.; Bhorat, Q.E.; et al. Safety and Efficacy of the ChAdOx1 NCoV-19 Vaccine (AZD1222) against SARS-CoV-2: An Interim Analysis of Four Randomised Controlled Trials in Brazil, South Africa, and the UK. Lancet 2021, 397, 99-111. [CrossRef] 
185. Voysey, M.; Clemens, S.A.C.; Madhi, S.A.; Weckx, L.Y.; Folegatti, P.M.; Aley, P.K.; Angus, B.; Baillie, V.L.; Barnabas, S.L.; Bhorat, Q.E.; et al. Single-Dose Administration and the Influence of the Timing of the Booster Dose on Immunogenicity and Efficacy of ChAdOx1 NCoV-19 (AZD1222) Vaccine: A Pooled Analysis of Four Randomised Trials. Lancet 2021, 397, 881-891. [CrossRef]

186. Haas, E.J.; Angulo, F.J.; McLaughlin, J.M.; Anis, E.; Singer, S.R.; Khan, F.; Brooks, N.; Smaja, M.; Mircus, G.; Pan, K.; et al. Impact and Effectiveness of MRNA BNT162b2 Vaccine against SARS-CoV-2 Infections and COVID-19 Cases, Hospitalisations, and Deaths Following a Nationwide Vaccination Campaign in Israel: An Observational Study Using National Surveillance Data. Lancet 2021, 397, 1819-1829. [CrossRef]

187. Vasileiou, E.; Simpson, C.R.; Robertson, C.; Shi, T.; Kerr, S.; Agrawal, U.; Akbari, A.; Bedston, S.; Beggs, J.; Bradley, D.; et al. Effectiveness of First Dose of COVID-19 Vaccines Against Hospital Admissions in Scotland: National Prospective Cohort Study of 5.4 Million People. SSRN Electron. J. 2021. [CrossRef]

188. Public Health England. COVID-19 Vaccine Surveillance Report Week 20; Public Health England: London, UK, $2021 ;$ pp. 1-22. Available online: https://assets.publishing.service.gov.uk/government/uploads/system/uploads/attachment_data/file/99 0089/Vaccine_surveillance_report_-_week_20.pdf (accessed on 30 October 2021).

189. Bernal, J.L.; Andrews, N.; Gower, C.; Robertson, C.; Stowe, J.; Tessier, E.; Simmons, R.; Cottrell, S.; Roberts, R.; O’Doherty, M.; et al. Effectiveness of the Pfizer-BioNTech and Oxford-AstraZeneca Vaccines on Covid-19 Related Symptoms, Hospital Admissions, and Mortality in Older Adults in England: Test Negative Case-Control Study. BMJ 2021, 373, n1088. [CrossRef]

190. Pritchard, E.; Matthews, P.C.; Stoesser, N.; Eyre, D.W.; Gethings, O.; Vihta, K.D.; Jones, J.; House, T.; VanSteenHouse, H.; Bell, I.; et al. Impact of Vaccination on New SARS-CoV-2 Infections in the United Kingdom. Nat. Med. 2021, 27, 1370-1378. [CrossRef]

191. Tenforde, M.W.; Olson, S.M.; Self, W.H.; Talbot, H.K.; Lindsell, C.J.; Steingrub, J.S.; Shapiro, N.I.; Ginde, A.A.; Douin, D.J.; Prekker, M.E.; et al. Effectiveness of Pfizer-BioNTech and Moderna Vaccines Against COVID-19 Among Hospitalized Adults Aged $\geq 65$ Years-United States, January-March 2021. MMWR Recomm. Rep. 2021, 70, 674-679. [CrossRef]

192. Moderna. Moderna's COVID-19 Vaccine Candidate Meets Its Primary Efficacy Endpoint in the First Interim Analysis of the Phase 3 COVE Study. Press Release 2020, 1273. Available online: https://investors.modernatx.com/news-releases/news-releasedetails/modernas-covid-19-vaccine-candidate-meets-its-primary-efficacy (accessed on 30 October 2021).

193. AztraZeneca. AZD1222 US Phase III Trial Met Primary Efficacy Endpoint in Preventing COVID-19 at Interim Analysis. Press Release 2020. Available online: https:/ / www.astrazeneca.com/media-centre/press-releases/2021/astrazeneca-us-vaccine-trialmet-primary-endpoint.html (accessed on 30 October 2021).

194. Polack, F.P.; Thomas, S.J.; Kitchin, N.; Absalon, J.; Gurtman, A.; Lockhart, S.; Perez, J.L.; Pérez Marc, G.; Moreira, E.D.; Zerbini, C.; et al. Safety and Efficacy of the BNT162b2 MRNA Covid-19 Vaccine. N. Engl. J. Med. 2020, 383, 2603-2615. [CrossRef] [PubMed]

195. Earle, K.A.; Ambrosino, D.M.; Fiore-Gartland, A.; Goldblatt, D.; Gilbert, P.B.; Siber, G.R.; Dull, P.; Plotkin, S.A. Evidence for Antibody as a Protective Correlate for COVID-19 Vaccines. Vaccine 2021, 39, 4423-4428. [CrossRef] [PubMed]

196. Kristiansen, P.A.; Page, M.; Bernasconi, V.; Mattiuzzo, G.; Dull, P.; Makar, K.; Plotkin, S.; Knezevic, I. WHO International Standard for Anti-SARS-CoV-2 Immunoglobulin. Lancet 2021, 397, 1347-1348. [CrossRef]

197. Centers of Disease Control and Prevalence: Large-scale Geographic Seroprevalence Surveys. Update 2 October 2020. Available online: https: / / www.cdc.gov / coronavirus/2019-ncov/cases-updates/geographic-seroprevalence-surveys.html (accessed on 4 May 2021).

198. Amanat, F.; Stadlbauer, D.; Strohmeier, S.; Nguyen, T.H.O.; Chromikova, V.; McMahon, M.; Jiang, K.; Arunkumar, G.A.; Jurczyszak, D.; Polanco, J.; et al. A Serological Assay to Detect SARS-CoV-2 Seroconversion in Humans. Nat. Med. 2020, 26, 1033-1036. [CrossRef]

199. Long, Q.X.; Liu, B.Z.; Deng, H.J.; Wu, G.C.; Deng, K.; Chen, Y.K.; Liao, P.; Qiu, J.F.; Lin, Y.; Cai, X.F.; et al. Antibody Responses to SARS-CoV-2 in Patients with COVID-19. Nat. Med. 2020, 26, 845-848. [CrossRef]

200. Wan, J.; Xing, S.; Ding, L.; Wang, Y.; Gu, C.; Wu, Y.; Rong, B.; Li, C.; Wang, S.; Chen, K.; et al. Human-IgG-Neutralizing Monoclonal Antibodies Block the SARS-CoV-2 Infection. Cell Rep. 2020, 32, 107918. [CrossRef] 